\title{
Molecular Imaging of Diabetic Foot Infections
}

\section{Diyabetik Ayak Enfeksiyonlarında Moleküler Görüntüleme}

\author{
Christopher J. Palestro
}

Hofstra Northwell Faculty of Medicine, Department of Radiology, New York, USA

*This article is reproduced from "Palestro JC, Love C, Nuclear Medicine and Diabetic Foot Infections. Semin Nucl Med 2009 Jan;39(1):52-65" as a new article.

\section{Abstract}

Diabetic foot infection, which is defined as an infection of the soft tissues or bone below the malleoli, is a common clinical problem. Diabetic patients can have a significant foot infection with few or no signs or symptoms and the diagnosis of osteomyelitis can easily be overlooked. As a result, imaging studies have become an integral part of the diagnostic workup of these patients. Although not especially sensitive or specific radiographs are routinely performed because they provide an anatomic overview of the area of interest and any pre-existing conditions that could potentially influence the selection and interpretation of subsequent procedures. Bone scintigraphy is sensitive but not specific, and if used at all, should be used as a screening procedure. In-vitro labeled leukocyte scintigraphy is, at the moment, the nuclear medicine gold standard for diagnosing diabetic pedal osteomyelitis, with sensitivity and specificity ranging from $72 \%$ to $100 \%$ and $67 \%$ to $100 \%$, respectively for $\mathrm{In}-111$ labeled leukocytes and $86 \%$ to $93 \%$ and $80 \%$ to $98 \%$, respectively, for Tc-99m labeled leukocytes. Results obtained with leukocytes labeled in-vivo with antigranulocyte antibodies and antibody fragments, have been more variable. Furthermore, these agents are not widely available. In-vitro and in-vivo labeled leukocyte imaging studies are limited by a combination of poor image resolution and the small size of the structures being evaluated. Incorporating single photon emission computed tomography/computed tomography (SPECT/CT) into the procedure improves the accuracy of the test by precisely localizing foci of labeled leukocyte accumulation, facilitating the differentiation of soft tissue and bone infection, and improving confidence of interpretation. Furthermore, the CT component of the examination may have prognostic

\section{Öz}

Malleol altından itibaren kemik veya yumuşak dokuların enfeksiyonu olarak tanımlanan diyabetik ayak enfeksiyonu sık görülen bir klinik problemdir. Diyabetik hastalar ciddi bir enfeksiyon geçiriyor oldukları halde çok az belirti gösterebilirler veya hiç belirti vermeyebilirler ve osteomiyelit tanısı kolayca gözden kaçabilir. Bu nedenle, görüntüleme çalışmaları bu hastalarda tanısal işleyişin vazgeçilmez bir parçası haline gelmiştir. Çok spesifik veya sensitif olmamalarına rağmen direkt grafiler tanıda rutin olarak kullanılmaktadır. İlgili alanın anatomik değerlendirmesine ve takip eden prosedürün seçimini ve değerlendirmesini etkileyebilecek, önceden var olan durumların belirlenmesine olanak sağlarlar. Kemik sintigrafisi, sensitif olmasına rağmen spesifik değildir ve eğer kullanılacaksa tarama testi olarak kullanılmalıdır. Günümüzde, in-vitro işaretli lökosit sintigrafisi, diyabetik pedal osteomiyelitinin tanısında nükleer tıbbın altın standart yöntemidir. In-111 işaretli lökositlerin sensitivitesi \%72-100, spesifitesi \%67-100 arasında, Tc-99m işaretli lökositlerin ise sensitivitesi \%86-93, spesifitesi \%8098 aralığında değişmektedir. İn-vivo olarak antigranülosit antikorları ve antikor fragmanları ile işaretlenen lökositlerle yapılmış çalışmaların sonuçları ise oldukça değişkendir. Ayrıca bu ajanlar her yerde bulunmamaktadır. İn-vitro ve invivo işaretli lökosit çalışmalarının, görüntü rezolüsyonunun kötü olması ve değerlendirilen yapıların küçük olması gibi kısıtlılıkları vardır. Tek foton emisyon bilgisayarlı tomografi/ bilgisayarlı tomografinin (SPECT/BT) prosedüre dahil edilmesi ile işaretli lökosit tutulum odağı kesin bir şekilde lokalize edilmekte, yumuşak doku ve kemik enfeksiyon ayrımı kolaylaşmakta ve değerlendirmenin güvenilirliği ve testin doğruluğu artmaktadır. Ayrıca yöntemin BT komponentinin 
value. Recent developments suggest that SPECT/CT also may be useful for determining the success of antibiotic treatment in diabetic patients with pedal osteomyelitis. F-18 fluorodeoxyglucose (FDG) positron emission tomography (PET) has several advantages over single photon emitting radiopharmaceuticals. PET is a high resolution tomographic technique. FDG is a small molecule that enters poorly perfused areas quickly. The procedure is completed in hours rather than days and no laborious labeling procedures are involved. Unfortunately, the available literature on the role of FDG-PET and PET/CT in the diagnostic workup of diabetic foot infections is inconclusive and at times contradictory. Large multicenter trials, including a uniform reference standard and more extensive comparison with labeled leukocyte imaging are needed to establish the role of this test in diabetic foot infections.

Keywords: Diabetes, flurodeoxyglucose, labeled leukocytes, osteomyelitis, PET/CT, SPECT/CT

\section{Introduction}

Diabetic foot infection, which is defined as an infection of the soft tissues or bone below the malleoli, is a common clinical problem. Most of these infections occur at a site of skin trauma or ulceration. The estimated lifetime risk of a person with diabetes mellitus developing a foot ulcer is $15 \%$ to $25 \%$, with an annual incidence of $3 \%$ to $10 \%$. Major predisposing factors include peripheral arterial disease, peripheral neuropathy, and compromised immunity. More than $50 \%$ of all nontraumatic lower extremity amputations are related to diabetic foot infections, and $85 \%$ of all lower extremity amputations in patients with diabetes are preceded by an ulcer $(1,2,3)$.

Any breach in the cutaneous integument of the foot in a person with diabetes has the potential to develop into severe soft-tissue and/or osseous infection. Osteomyelitis should be considered in all patients with a chronic non healing wound, especially when the wound extends beyond the dermis. The exposed bone or probe to bone test, which is easy to perform, has a sensitivity and specificity of $60 \%$ and $91 \%$, respectively, for diagnosing osteomyelitis underlying an open wound (4). Diabetic patients, however, can have a significant foot infection with few or no signs or symptoms and without mounting a systemic inflammatory response and the diagnosis of osteomyelitis in these individuals can easily be overlooked (5). As a result, imaging studies prognostik değeri de vardır. Yakın zamandaki gelişmeler, pedal osteomiyeliti olan diyabetik hastalarda antibiyotik tedavisinin başarısını değerlendirmede SPECT/BT'nin yararlı olabileceğini göstermiştir. F-18 florodeoksiglikoz (FDG) pozitron emisyon tomografinin (PET) tek foton emisyonu yapan radyofarmasötiklere oranla pek çok avantajı bulunmaktadır. PET, yüksek rezolüsyonlu tomografik bir tekniktir. FDG, perfüzyonu kötü alanlara bile hızlıca girebilen küçük bir moleküldür. İşlem günler yerine saatler içinde tamamlanır ve zahmetli bir işaretleme prosedürü gerektirmez. Maalesef, FDG-PET ve PET/BT'nin diyabetik ayak enfeksiyonlarının tanısal işleyişindeki rolü ile ilgili veriler yetersiz ve zaman zaman da çelişkilidir. Bu testin diyabetik ayak enfeksiyonlarındaki rolünü değerlendirmek için uniform bir referans standardı ve işaretli lökosit görüntüleme ile daha kapsamlı karşılaştırmalar içeren geniş, çok merkezli çalışmalar gerekmektedir.

Anahtar kelimeler: Diyabet, florodeoksiglikoz, lökosit işaretli, osteomiyelit, PET/BT, SPECT/BT

have become an integral part of the diagnostic workup of the diabetic patient with a foot infection.

In spite of a sensitivity of only about $54 \%$ and a specificity of about $68 \%$, radiographs, which are nearly universally available and relatively inexpensive, should be the first imaging test performed. Even when not diagnostic, radiographs provide an anatomic overview of the area of interest and any pre-existing conditions that could influence both the selection and interpretation of subsequent procedures (4). Although magnetic resonance imaging plays an important role in the diagnostic evaluation of the diabetic patient with a foot infection, a discussion of this technique is beyond the scope of this review, which will focus on molecular imaging studies.

\section{Molecular Imaging}

\section{Bone Scintigraphy}

Focal hyperperfusion, focal hyperemia, and focal bony uptake are the classic presentation of osteomyelitis on three phase bone scintigraphy. Many of the conditions to which the diabetic patient with foot problems is prone, however, including fracture, the neuropathic joint, and even the pedal ulcer, can mimic osteomyelitis (Figure 1, 2) (6). Sensitivity and specificity of the three phase bone scan range from $75 \%$ to $100 \%$ and $0 \%$ to $59 \%$, respectively $(7,8,9,10,11,12,13,14,15,16,17,18)$. Attempts at improving the specificity of the three phase 
bone scan, including differentiating arterial from venous hyperperfusion on the flow phase of the study and the addition of delayed, next day, imaging, the so called four phase bone scan, have yielded mixed results and are not widely used $(19,20,21,22,23)$.

\section{Labeled Leukocyte Imaging}

In-vitro labeled leukocyte scintigraphy has long been considered the molecular imaging gold standard for diagnosing diabetic pedal osteomyelitis. The sensitivity of the test, using In-111 labeled leukocytes with planar imaging, has ranged from $72 \%$ to $100 \%$ and the specificity from $67 \%$ to $100 \%[7-10,14,20,21]$ (Figure 3). The sensitivity and specificity of technetium$99 \mathrm{~m}$ exametazime labeled leukocyte planar imaging for diagnosing diabetic pedal osteomyelitis range from $86 \%$ to $93 \%$ and from $80 \%$ to $98 \%$, respectively $(11,12,13,17,24)$.

The limitations to in-vitro labeled leukocyte imaging are well known. The labeling procedure requires skilled personnel, is laborious, not always available, and involves direct contact with blood. Considerable effort, therefore, has been devoted to the development of in-vivo leukocyte labeling methods. Most of these investigations have focused on the use of antigranulocyte antibodies and antibody fragments.
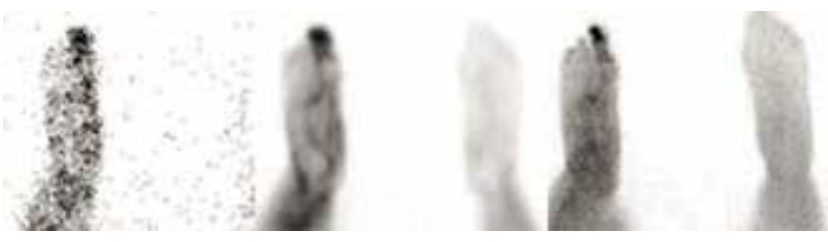

Figure 1. Osteomyelitis right great toe. There is focal hyperperfusion, focal hyperemia, and focally increased bone activity in the right great toe on the three phase bone scan. (Reproduced with permission from Palestro CJ, Love C. Nuclear medicine and diabetic foot infections. Semin Nucl Med. 2009;39:52-65.)
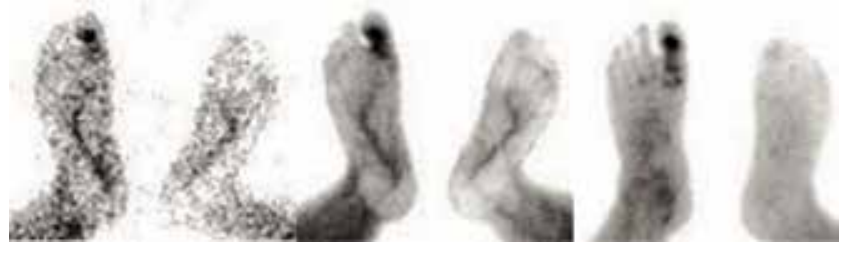

Figure 2. Reactive bone left great toe. There is focal hyperperfusion, focal hyperemia, and focally increased bone activity in the left great toe, indistinguishable from osteomyelitis. Compare with Figure 1. (Reproduced with permission from Palestro CJ, Love C. Nuclear medicine and diabetic foot infections. Semin Nucl Med. 2009;39:52-65.)
Besilesomab is a murine monoclonal immunoglobulin G1 (IgG1) antibody that binds to the nonspecific crossreacting antigen-95, which is expressed on granulocyte and granulocyte precursor cell membranes. About $10 \%$ of Tc- $99 \mathrm{~m}$ besilesomab is neutrophil bound within 45 minutes after administration. Another $20 \%$ circulates freely and presumably localizes in infection through nonspecific mechanisms (25). Dominguez-Gadea et al. reported that Tc-99m besilesomab was $93 \%$ sensitive, $78 \%$ specific, and $84 \%$ accurate for diagnosing pedal osteomyelitis in diabetics (26). Schwegler et al. reported sensitivity, specificity and accuracy of $29 \%, 85 \%$ and $65 \%$, respectively, for diabetic pedal osteomyelitis (27). The incidence of human antimurine antibody (HAMA) response in patients receiving Tc-99m besilesomab, which ranges from less than $5 \%$ in patients receiving a single dose of 125 ug of the antibody to more than $30 \%$ in individuals receiving repeated injections is a significant disadvantage to the test. Consequently, patients should be prescreened for HAMA, should not be injected with more than 250 ug antibody and should not undergo repeat administration (25).

Antibody fragments do not induce a HAMA response. Sulesomab is a $50 \mathrm{kDa}$ fragment antigen binding ( $\mathrm{Fab}^{\prime}$ ) portion of an IgG1 class murine monoclonal antibody that binds to normal cross-reactive antigen- 90 present on leukocytes. Approximately 3-6\% of the Tc- 99 m sulesomab injected is associated with circulating neutrophils; by 24 hours after injection, about $35 \%$ of the remaining activity is in the bone marrow. Initial investigations suggested that sulesomab uptake in infection includes binding to circulating neutrophils that subsequently migrate to foci of infection and binding to leukocytes already present at the site of infection. There are other data, however, that suggest that sulesomab does not bind to circulating leukocytes, and that it accumulates in infection nonspecifically through increased capillary membrane

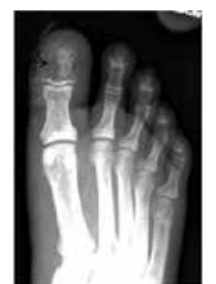

A

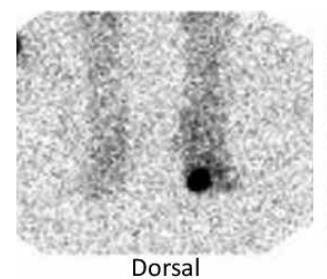

B

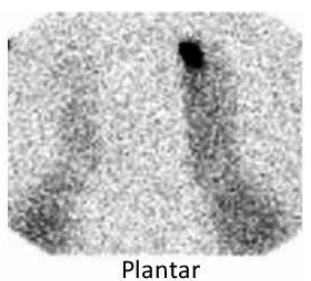

Plantar
Figure 3. Osteomeyelitis left great toe. Radiograph (A) demonstrates soft tissue swelling, skin ulceration medially, and irregular osteolysis of the distal phalanx. There is focally increased activity on the dorsal and plantar In-111 labeled leukocyte images (B) 
permeability (25). In a prospective investigation, Delcourt et al. compared combined Tc-99m sulesomab/ bone imaging to combined bone/gallium imaging in 25 diabetic patients. The sensitivity, specificity, and accuracy of Tc-99m sulesomab/bone imaging were $67 \%$, $85 \%$, and $74 \%$ versus $44 \%, 77 \%$, and $58 \%$, respectively for bone/gallium imaging (28). Harwood et al. studied 122 diabetic patients with foot ulcers and reported that Tc-99m sulesomab had $91 \%$ sensitivity, 56\% specificity, and $80 \%$ accuracy for diagnosing pedal osteomyelitis (29). The test was significantly more sensitive (92\% vs. $79 \%$ p $<0.05$ ), and slightly less specific (58\% vs. 67\%) than in-vitro labeled leukocyte imaging and significantly more specific than bone scintigraphy ( $50 \%$ vs. $21 \%$; $p<0.05)$.

The accuracy of both in-vitro and in-vivo labeled leukocyte imaging is limited by a combination of poor image resolution and the small size of the structures being evaluated. Several investigators have used single photon emission computed tomography/computed tomography (SPECT/CT) to improve the accuracy of the test. Heiba et al. observed that, even when performed as a SPECT/ CT study, it was not always possible to differentiate between soft tissue infection and osteomyelitis on indium labeled leukocyte studies (30). They investigated simultaneous dual isotope labeled leukocyte/ bone SPECT/CT, and when necessary, bone marrow SPECT/CT, in 213 diabetic patients. They found that simultaneous dual isotope SPECT/CT was significantly more accurate than planar imaging and single isotope bone and InWBC SPECT/CT. Performing simultaneous dual isotope labeled leukocyte/bone SPECT/CT facilitated precise localization of labeled leukocyte accumulation, thereby improving confidence of interpretation and test accuracy. In another investigation, Heiba et al. compared simultaneous dual isotope, labeled leukocyte/bone SPECT/CT to conventional imaging for diagnosing and managing foot infections in diabetic patients (31).
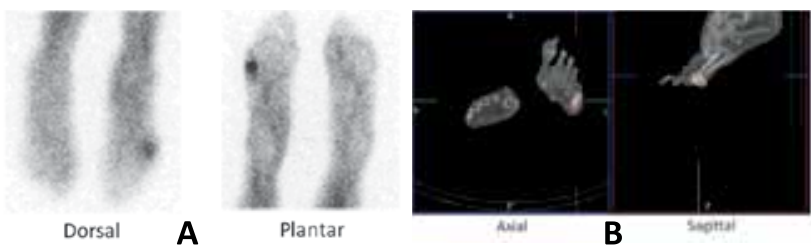

Figure 4. Osteomyelitis left fifth metatarsal/phalanx. On the planar In-111 labeled leukocyte images there is a focus of increased activity overlying the lateral aspect of the distal left foot. On the single photon emission computed tomography/computed tomography images it can be seen that this focus involves both soft tissue and bone
Compared to conventional imaging studies, dual isotope SPECT/CT resulted in higher reader confidence and more accurate diagnosis of soft-tissue infection, osteomyelitis and other bony abnormalities. Dual isotope SPECT/CT also provided clear guidance on patient management and resulted in more limb salvage procedures instead of amputations. Equally important, from an economic standpoint, compared to conventional imaging, the use of dual isotope SPECT/CT resulted in considerably decreased length of hospitalization.

An alternative to dual isotope SPECT/CT is to use technetium rather than indium labeled leukocytes. Technetium offers superior resolution and labeling and imaging both can be performed on the same day. Filippi et al. performed planar and SPECT/CT technetium labeled leukocyte imaging on seventeen diabetic patients with 19 suspected sites of infection. SPECT/CT was performed six hours after reinfusion of labeled cells (32). Labeled leukocyte imaging was positive in 16 of the 19 sites. SPECT/CT changed the interpretation of planar and SPECT images in 10 (53\%) of the sites, by excluding osteomyelitis in six sites, identifying bone and soft tissue
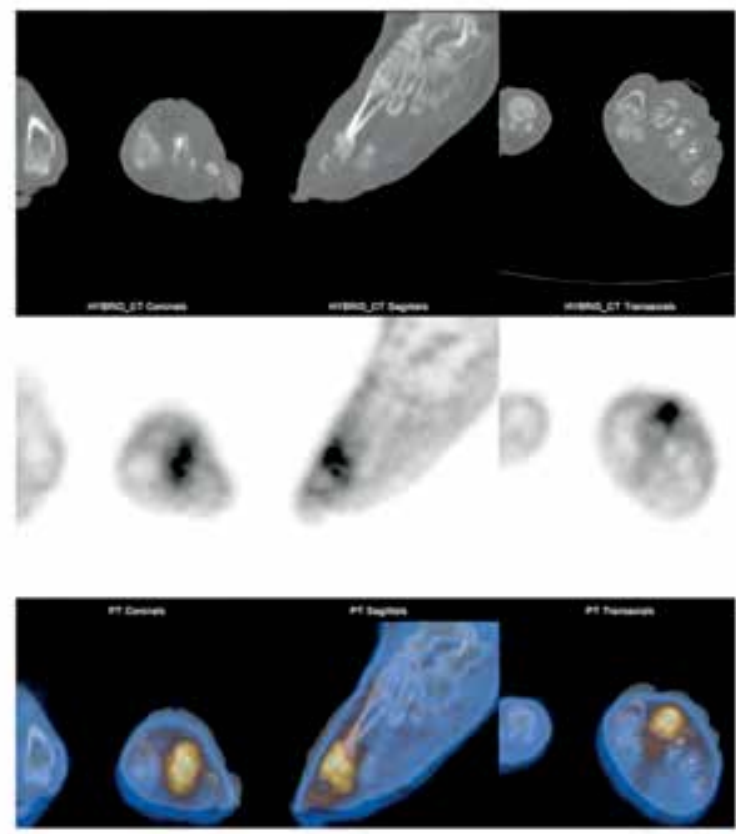

Figure 5. Osteomyelitis/septic arthritis left forefoot. On the fluorodeoxyglucose positron emission tomography image there is increased activity in the left forefoot, but it is difficult to determine whether the activity involves the bone. The positron emission tomography/computed tomography images show that the activity involves the distal left second metatarsal, the proximal second left phalanx and the metatarsal phalangeal joint space. (Courtesy of O. Israel, M.D.) 
infection in three sites and identifying osteomyelitis in one site. These investigators concluded that the accuracy of diagnosing diabetic pedal osteomyelitis with technetium labeled leukocyte imaging is improved by incorporating SPECT/CT into the imaging protocol. Przybylski et al. retrospectively reviewed the results of technetium labeled leukcoyte SPECT/CT performed on 14 diabetic patients, all of whom had pedal ulcers (33). Five of the patients also had peripheral arterial disease. Imaging was performed about three hours after labeled leukocyte reinfusion. The sensitivity, specificity, and accuracy of the test were $87.5 \%, 71.4 \%$, and $80 \%$, respectively.

Erdman et al. in an effort to classify the severity of diabetic foot infections for prognostic purposes, developed a scoring system, the Composite Severity Index (CSI) for technetium labeled leukcoyte SPECT/ CT (34). They hypothesized that analyzing certain key anatomic and molecular imaging parameters on the SPECT/CT images could provide both diagnostic and prognostic information. They retrospectively analyzed and graded the intensity of labeled leukocyte uptake, the number and anatomic location of the lesions, and on the CT component of the test, the presence or absence of adjacent disrupted bone architecture. The CSI was derived from these data and was compared to a binary interpretation (positive or negative for osteomyelitis), of the images. These investigators observed that the likelihood of a favorable outcome varied inversely with the CSI score. As the CSI score increased, the likelihood of a favorable outcome decreased and the likelihood of treatment failure increased. The CSI was significantly
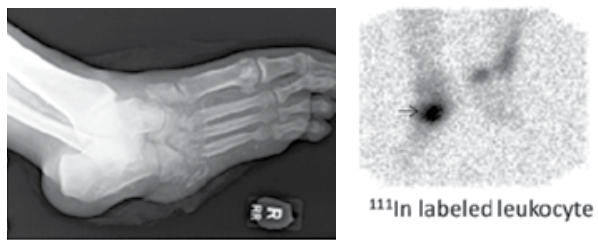

${ }^{111}$ In labeled leukocyte

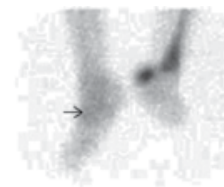

${ }^{99 m}$ Tc sulfur colloid A

Figure 6. Osteomyelitis of a neuropathic joint. (A) The radiograph demonstrates midfoot joint derangement with extensive osseous erosions, increased bony fragmentation, and debris formation consistent with a neuropathic joint. It is difficult to exclude superimposed osteomyelitis. (B) On the In-111 labeled leukocyte image (left), there is intensely increased activity in the right mid foot (arrow). On the bone marrow image (right) there is no corresponding activity (arrow), and the combined study is positive for osteomyelitis. Note also the increased activity in the left hind foot on both the labeled leukocyte and bone marrow images. This indicates the presence of functioning bone marrow, not infection more accurate $(p=0.016)$ than binary interpretation for predicting therapeutic outcome.

Over the years, the vast majority of the investigations have focused on the role of labeled leukocyte imaging for diagnosing diabetic foot infections, with scant attention paid to monitoring response to treatment.

Newman et al. studied serial planar indium labeled leukocyte imaging in 35 diabetic patients with 41 pedal ulcers, including 28 with biopsy proven underlying osteomyelitis (20). They observed that the intensity of labeled leukocyte activity decreased by 16 to 34 days and normalized by 36 to 54 days of appropriate antibiotic treatment. They did not, however, use this information for prognostic purposes. More recently, data are emerging that suggest that technetium labeled leukocyte SPECT/ CT may be useful for monitoring treatment response in diabetics with pedal osteomyelitis. Vouillarmet et al. compared radiographs, three phase bone scintigraphy, and technetium labeled leukocyte SPECT/CT for assessing pedal osteomyelitis remission, which was defined as an absence of relapsed osteomyelitis after one year follow up, in 29 patients (35). Radiographs showed no improvement or progression from baseline in 20 patients, 16 of whom had relapsed osteomyelitis. There was radiographic improvement in nine patients, including one with relapsed osteomyelitis. Three phase bone scintigraphy was positive in 26 patients; only five developed relapsed osteomyelitis. The test was negative in three patients, none of whom developed relapsed osteomyelitis. Technetium labeled leukocyte SPECT/ CT, performed 20 hours after reinfusion of labeled leukocytes, was negative in 22 patients, none of whom developed relapsed osteomyelitis. Seven studies were positive for osteomyelitis, including five with relapsed infection. Sensitivity, specificity, and positive and negative predictive values for predicting osteomyelitis relapse after completion of antibiotic treatment were $80 \%, 33 \%, 20 \%$ and $89 \%$, respectively for radiographs; $100 \%, 12.5 \%, 15.5 \%$ and $100 \%$, respectively for threephase bone scintigraphy; and $100 \%, 91.5 \%, 71.5 \%$ and $100 \%$, respectively, for technetium labeled leukocyte SPECT/CT. The authors concluded that a negative test reliably identifies diabetic foot osteomyelitis remission and potentially could be very useful for guiding antibiotic therapy.

Lazaga et al. retrospectively reviewed pre- and post treatment technetium labeled leukocyte SPECT/CT in 20 diabetic patients with pedal osteomyelitis to assess the value of this test for monitoring response to treatment (36). Successful treatment of osteomyelitis was defined 
as wound healing or lack of re-admission for bone infection at the same site within 1 year. The sensitivity, specificity, and positive and negative predictive values for determining success of treatment were $90 \%, 56 \%$, $69 \%$ and $83 \%$, respectively.

These preliminary results suggest that technetium labeled leukocyte SPECT/CT may be useful for monitoring response to treatment in diabetic patients with pedal osteomyelitis. The test appears to be especially valuable when it is negative, making relapsed infection very unlikely.

\section{F-18 Fluorodeoxyglucose}

F-18 fluorodeoxyglucose (FDG) positron emission tomography (PET) has several advantages over single photon emitting radiopharmaceuticals. PET intrinsically is a high resolution tomographic technique that enables precise localization of radiopharmaceutical accumulation. FDG is a small molecule that enters poorly perfused areas quickly. The procedure is completed in hours rather than in days, and in contrast to in-vitro labeled leukocytes, no laborious labeling procedures are required. FDG uptake in traumatized bone usually normalizes within three to four months and degenerative bone changes usually show only mildly increased uptake (6).

Several groups have investigated the role of FDG-PET and PET/CT in the evaluation of diabetic foot infections. Nawaz et al. prospectively compared FDG-PET, plain radiography, and magnetic resonance imaging (MRI) for diagnosing pedal osteomyelitis in 110 diabetic patients, although not all patients underwent all three studies (37). All patients had a blood glucose level below $200 \mathrm{mg}$ / dL. Images were interpreted visually; SUV was not used. Sensitivity, specificity, positive and negative predictive values, and accuracy of FDG-PET were $81 \%$, 93\%, 78\%, $94 \%$, and $90 \%$, respectively. Sensitivity, specificity, positive and negative predictive values, and accuracy of MRI were $91 \%, 78 \%, 56 \%, 97 \%$, and $81 \%$, respectively. Sensitivity, specificity, positive and negative predictive values and accuracy of radiographs were $63 \%, 87 \%$, $60 \%, 88 \%$, and $81 \%$, respectively. The authors concluded that FDG-PET is highly specific for diagnosing diabetic pedal osteomyelitis and is a useful compliment to MRI. The authors also suggested that when MRI cannot be performed FDG-PET can be used after negative or inconclusive radiographs. The vast majority of diabetic patients with pedal osteomyelitis present with ulcers involving the distal forefoot; pedal osteomyelitis in the absence of an ulcer is uncommon. Unfortunately data about the areas of interest (forefoot, mid foot, hind foot) and the number of patients with soft tissue ulcers were not provided, which makes it difficult to assess the significance of the findings in this investigation. The results obtained by Schwegler at al. were very different (27). These investigators, who also used only visual image analysis, prospectively evaluated FDG-PET for diagnosing clinically unsuspected osteomyelitis in 20 diabetic patients with nonhealing pedal ulcers. The ulcers were located in the forefoot in 18 patients and in the hind foot in two patients. Information on blood glucose levels at the time of imaging was not provided. Sensitivity, specificity and accuracy were $29 \%, 92 \%$ and $70 \%$, respectively, for FDG PET and $86 \%$, 92\% and $90 \%$, respectively, for MRI. The investigators speculated that the low sensitivity of the test may have been related to a diminished inflammatory response in the study population and/or to impaired bony uptake of FDG, because of insulin resistance. Motion artifacts and limited spatial resolution may have been additional contributing factors. The authors concluded MRI might be the preferred imaging modality for diagnosing osteomyelitis in diabetic patients with non healing pedal ulcers.

Yang et al. studied 48 diabetic patients with suspected pedal osteomyelitis, including 27 with serum glucose levels above $150 \mathrm{mg} / \mathrm{dL}$ (38). The accuracy of FDG-PET was $93.8 \%$. Sensitivity was $88.9 \%$ for patients with serum glucose levels above $150 \mathrm{mg} / \mathrm{dL}$ and $88.3 \%$ for patients with serum glucose levels below $150 \mathrm{mg} /$ $\mathrm{dL}$. They concluded that a mildly to moderately elevated serum glucose level does not affect FDG-PET accuracy for detecting pedal osteomyelitis in diabetic patients.

Keidar et al. compared FDG-PET and PET/CT in 14 diabetic patients with 18 clinically suspected sites of infection, including seven in the forefoot, one in the mid foot, and ten in the hind foot (39). Blood glucose levels ranged from $84 \mathrm{mg} / \mathrm{dL}$ to $330 \mathrm{mg} / \mathrm{dL}$. Seven patients had blood glucose levels in excess of $200 \mathrm{mg} / \mathrm{dL}$. There were 14 foci of abnormal uptake on the PET images consistent with infection. PET/CT confirmed the diagnosis in 13 of the 14 sites, correctly localizing the abnormalities to bone in 8 sites to bone and to the soft-tissues in five sites. One site, thought to be infection on PET images, was identified as diabetic osteoarthropathy on PET/ CT images. Maximum SUV in the sites of abnormal FDG uptake ranged from 1.4 to 11.1. There was no relationship between the patients' blood glucose level and degree of FDG uptake. The authors concluded that FDG can be used for diagnosing diabetes-related foot 
infection and that by performing PET/CT it is possible to accurately differentiate osteomyelitis from softtissue infection (Figure 5). Kagna et al. in an expansion of this investigation reported sensitivity, specificity, and accuracy of $100 \%, 93 \%$, and $96 \%$, respectively for the diagnosis of diabetic pedal osteomyelitis (40).

Familiari et al. compared FDG-PET/CT to planar Tc-WBC imaging in 13 diabetic patients with a high pretest likelihood of foot infection (41). All 13 patients had a blood glucose level of less than $160 \mathrm{mg} / \mathrm{dL}$. Histopathologic confirmation of the final diagnosis was available for all cases. Both FDG-PET/CT and technetium labeled leukocyte planar imaging were performed at multiple time points. Sensitivity, specificity, positive predictive value, negative predictive value, and accuracy of technetium labeled leukocyte imaging for diagnosing osteomyelitis were $86 \%, 100 \%, 100 \%, 86 \%$, and $92 \%$, respectively. Sensitivity, specificity, positive predictive value, negative predictive value, and accuracy of FDG PET/CT for diagnosing osteomyelitis were $43 \%, 67 \%$, $60 \%, 50 \%$, and $54 \%$, respectively. Accuracy of FDG PET/ CT improved to $62 \%$, when CT findings were incorporated into the image interpretation. The investigators concluded that FDG PET/CT has a low diagnostic accuracy and cannot replace labeled leukocyte imaging for diagnosing pedal osteomyelitis in diabetics.

The majority of diabetic patients with diabetic foot infections present with an ulcer in the distal forefoot. The neuropathic, or Charcot, joint, which is much less common than, and not always associated with, an ulcer, usually develops in the diabetic mid or hind foot. The tarsal and tarsometatarsal or Lisfranc joints are the most frequently involved locations $(60 \%)$ followed by the metatarsophalangeal joints (30\%) and the tibiotalar joint (10\%). Differentiating infection from the neuropathic joint or diagnosing infection superimposed on the neuropathic joint is challenging. Three-phase bone scintigraphy invariably is positive in both conditions. Labeled leukocytes accumulate in both the infected and the uninfected neuropathic joint. Accumulation in the uninfected neuropathic joint is due, at least in part, to hematopoietically active marrow in the involved bones. Performing complementary bone marrow imaging accurately differentiates labeled leukocyte uptake due to bone marrow from that due to infection (Figure 6) (42). Palestro et al. reported an accuracy of $95 \%$ for planar In-WBC/bone marrow imaging. Heiba et al. reported similar results using dual isotope SPECT/CT $(30,43)$.

Data on the role of FDG PET and PET/CT in the evaluation of the neuropathic joint are limited. Höpfner et al. performed FDG-PET on 16 diabetic patients to determine the value of the test in the preoperative evaluation of the neuropathic joint (44). None of the patients in this investigation had osteomyelitis. The investigators suggested that, even though none of the patients studied had diabetic foot infection, because of the relatively low uptake in the uninfected neuropathic joint, FDG-PET could be useful for differentiating osteomyelitis from neuropathic lesions. Shagos et al. compared FDG-PET to three phase bone scintigraphy in the evaluation of diabetic foot complications including osteomyelitis $(n=36)$ and the neuropathic joint $(n=43)$ (15). They reported that FDG-PET was more specific than bone scintigraphy for osteomyelitis, while bone scintigraphy was more sensitive than FDG-PET for the neuropathic joint. Basu et al. investigated the ability of FDG-PET to differentiate pedal osteomyelitis and soft tissue infection from the uninfected neuropathic joint (45). The sensitivity and accuracy of FDG-PET for diagnosing osteomyelitis were $100 \%$ and $94 \%$. The investigators concluded that FDG-PET had a high negative predictive value for excluding osteomyelitis in the presence of the neuropathic joint. Unfortunately only one patient in this investigation had osteomyelitis superimposed on the neuropathic joint.

Based on available evidence it is not possible to conclude that FDG PET or even PET/CT should be the molecular imaging test of choice for diabetic pedal osteomyelitis. The limitations of the available data include variable methodology, different patient populations, variable image interpretation, (visual versus SUV), lack of information about the presence or absence of vascular insufficiency, inconsistent correlation with MRI, a paucity of comparative studies with labeled leukocyte imaging, and lack of a uniform standard of truth $(46,47)$. Treglia et al. in a meta-analysis, reported a sensitivity and specificity of $74 \%$ and $91 \%$, respectively for FDG for diagnosing diabetic pedal osteomyelitis and commented that the literature on FDG imaging in suspected diabetic pedal osteomyelitis remains limited and large multicenter studies using bone biopsy as the reference standard are needed (47).

\section{Conclusion}

The diagnosis of pedal osteomyelitis in a diabetic patient with a foot infection is often overlooked and imaging studies have become an integral part of the diagnostic workup of these patients. At the present time, in-vitro labeled leukocyte imaging is the molecular imaging test of choice for this population. Published data 
suggest that either In-111 or Tc-99m labeled leukocytes can be used, with comparable results. Regardless of the radiolabel used, however, SPECT/CT should routinely be performed. Incorporating SPECT/CT into the procedure improves both reader confidence and test accuracy. SPECT/CT may also have prognostic value and be useful for monitoring response to treatment. The concept of using FDG PET and PET/CT in the diagnostic evaluation of the diabetic foot infection is exciting, but more extensive investigations are needed before any conclusions about its role can be drawn.

\section{References}

1. Gemechu FW, Seemant F, Curley CA. Diabetic foot infections. Am Fam Physician. 2013;88:177-184.

2. Lipsky BA, Berendt AR, Cornia PB, et al. 2012 Infectious Diseases Society of America clinical practice guideline for the diagnosis and treatment of diabetic foot infections. Clin Infect Dis 2012;54:132-173.

3. Boulton AJ, Vileikyte L, Ragnarson-Tennvall G, Apelqvist J. The global burden of diabetic foot disease. Lancet 2005;366:17191724.

4. Dinh MT, Abad CL, Safdar N. Diagnostic accuracy of the physical examination and imaging tests for osteomyelitis underlying diabetic foot ulcers: meta-analysis. Clin Infect Dis 2008;47:519-527.

5. Anderson CA, Roukis TS. The diabetic foot. Surg Clin N Am 2007;87:1149-1177.

6. Palestro CJ. Radionuclide imaging of osteomyelitis. Sem Nucl Med 2015;45:32-46.

7. Keenan AM, Tindel NL, Alavi A. Diagnosis of pedal osteomyelitis in diabetic patients using current scintigraphic techniques. Arch Intern Med 1989;149:2262-2266.

8. Larcos G, Brown ML, Sutton R. Diagnosis of osteomyelitis of the foot in diabetic patients: value of 111 In-leukocyte scintigraphy. AJR Am J Roentgenol 1991;157:527-531.

9. Maurer $\mathrm{AH}$, Millmond $\mathrm{SH}$, Knight LC, et al. Infection in diabetic osteoarthropathy: Use of indium-labeled leukocytes for diagnosis. Radiology 1986;151: 221-225.

10. Johnson JE, Kennedy EJ, Shereff MJ, Patel NC, Collier BD. Prospective study of bone, indium-111-labeled white blood cell, and gallium-67 scanning for the evaluation of osteomyelitis in the diabetic foot. Foot Ankle Int 1996;17;1016.

11. Devillers A, Moissan A, Hennion F, Garin E, Poirier JY, Bourguet P. Contribution of technetium-99m hexamethylpropylene amine oxime labeled leucocyte scintigraphy to the diagnosis of diabetic foot infection. Eur J Nucl Med 1998;25:132-138.

12. Harvey J, Cohen MM. Technetium-99-labeled leukocytes in diagnosing diabetic osteomyelitis in the foot. J Foot Ankle Surg 1997;36:209-214.
13. Blume PA, Dey HM, Dailey LJ, Arrighi JA, Soufer R, Gorecki GA. Diagnosis of pedal osteomyelitis with Tc-99m HMPAO labeled leukocytes. J Foot Ankle Surg 1997;36:120-126.

14. Palestro CJ, Caprioli R, Love $C$, et al. Rapid diagnosis of pedal osteomyelitis in diabetics with a technetium-99m labeled monoclonal antigranulocyte antibody. J Foot Ankle Surg 2003;42:2-8.

15. Shagos GS, Shanmugasundaram $P$, Varma AK, Padma S, Sarma M. 18-F flourodeoxy glucose positron emission tomographycomputed tomography imaging: A viable alternative to three phase bone scan in evaluating diabetic foot complications? Indian J Nucl Med 2015;30:97-103.

16. Sarikaya A, Aygit AC, Pekindil G. Utility of 99mTc dextran scintigraphy in diabetic patients with suspected osteomyelitis of the foot. Ann Nucl Med 2003;17:669-676.

17. Scheidler J, Leinsinger G, Pfahler M, Kirsch CM. Diagnosis of osteomyelitis. Accuracy and limitations of antigranulocyte antibody imaging compared to three-phase bone scan. Clin Nucl Med 1994;19:731-737.

18. Yuh WT, Corson JD, Baraniewski HM, et al. Osteomyelitis of the foot in diabetic patients: evaluation with plain film, 99mTc-MDP bone scintigraphy, and MR imaging. AJR Am J Roentgenol 1989;152:795-800.

19. Seldin DW, Heiken J, Feldman F, Alderson PO. Effect of soft tissue pathology on detection of pedal osteomyelitis in diabetics. J Nucl Med1985;26:988-993.

20. Newman LG, Waller J, Palestro CJ, et al. Unsuspected osteomyelitis in diabetic foot ulcers. Diagnosis and monitoring by leukocyte scanning with indium In 111 oxyquinoline. J Am Med Assoc 1991;266:1246-1251.

21. Johnson JE, Kennedy EJ, Shereff MJ, Patel NC, Collier BD. Prospective study of bone, indium-111-labeled white blood cell, and gallium-67 scanning for the evaluation of osteomyelitis in the diabetic foot. Foot Ankle Int 1996;17:10-16.

22. Alazraki N, Dries D, Datz F, Lawrence P, Greenberg E, Taylor A Jr. Value of a 24-hour image (four-phase bone scan) in assessing osteomyelitis in patients with peripheral vascular disease. J Nucl Med 1985;26:711-717.

23. Israel O, Gips S, Jerushalmi J, Frenkel A, Front D. Osteomyelitis and soft-tissue infection: differential diagnosis with 24 hour $/ 4$ hour ratio of Tc-99m MDP uptake. Radiology 1987;163:725726.

24. Poirier JY, Garin E, Derrien C, et al. Diagnosis of osteomyelitis in the diabetic foot with 99mTc-HMPAO leukocyte scintigraphy combined with a 99mTc-MDP bone scintigraphy. Diabetes Metab 2002;28:485-490.

25. Palestro CJ, Glaudemans AWJM, Dierckx RAJO. Multiagent imaging of inflammation and infection with radionuclides. Clin Transl Imaging 2013;1:385-396.

26. Dominguez-Gadea L, Martin-Curto LM, de la Calle H, Crespo A. Diabetic foot infections: scintigraphic evaluation with 99Tcm-labelled anti-granulocyte antibodies. Nucl Med Commun 1993;14:212-218. 
27. Schwegler B, Stumpe KD, Weishaupt D, et al.Unsuspected osteomyelitis is frequent in persistent diabetic foot ulcer and better diagnosed by MRI than by $18 \mathrm{~F}-\mathrm{FDG}$ PET or $99 \mathrm{mTc}-$ MOAB. J Intern Med 2008;263:99-106.

28. Delcourt A, Huglo D, Prangere $T$, et al. Comparison between Leukoscan (Sulesomab) and gallium-67 for the diagnosis of osteomyelitis in the diabetic foot. Diabetes Metab 2005;31:125-133.

29. Harwood SJ, Valdivia S, Hung GL, Quenzer, RW. Use of sulesomab, a radiolabeled antibody fragment, to detect osteomyelitis in diabetic patients with foot ulcers by leukoscintigraphy. Clin Infect Dis 1999;28:1200-1205.

30. Heiba SI, Kolker D, Mocherla B, et al. The optimized evaluation of diabetic foot infection by dual isotope SPECT/CT imaging protocol. J Foot Ankle Surg 2010;49:529-536.

31. Heiba S, Kolker D, Ong L, et al. Dual-isotope SPECT/CT impact on hospitalized patients with suspected diabetic foot infection: saving limbs, lives, and resources. Nucl Med Commun 2013;34:877-884.

32. Filippi L, Uccioli L, Giurato L, Schillaci O. Diabetic foot infection: usefulness of SPECT/CT for 99mTc-HMPAO-labeled leukocyte imaging. J Nucl Med 2009;50:1042-1046.

33. Przybylski MM, Holloway S, Vyce SD, Obando A. Diagnosing osteomyelitis in the diabetic foot: a pilot study to examine the sensitivity and specificity of $\mathrm{Tc}(99 \mathrm{~m})$ white blood celllabelled single photon emission computed tomography/ computed tomography. Int Wound J 2016;13:382-389.

34. Erdman WA, Buethe J, Bhore R, et al. Indexing severity of diabetic foot infection with $99 \mathrm{mTC}-\mathrm{WBC}$ SPECT/CT hybrid imaging. Diabetes Care 2012;35:1826-1831.

35. Vouillarmet J, Morelec I, Thivolet C. Assessing diabetic foot osteomyelitis remission with white blood cell SPECT/CT imaging. Diabet Med 2014;31:1093-1099.

36. Lazaga F, Van Asten SA, Nichols A, et al. Hybrid imaging with 99mTc-WBC SPECT/CT to monitor the effect of therapy in diabetic foot osteomyelitis. Int Wound J 2015.

37. Nawaz A, Torigian DA, Siegelman ES, Basu S, Chryssikos T, Alavi A. Diagnostic performance of FDG-PET, MRI, and plain film radiography (PFR) for the diagnosis of osteomyelitis in the diabetic foot. Mol Imaging Biol 2010;12:335-342.

38. Yang $H$, Zhuang $H$, Rubello D, Alavi A. Mild-to-moderate hyperglycemia will not decrease the sensitivity of 18F-FDG PET imaging in the detection of pedal osteomyelitis in diabetic patients. Nucl Med Commun 2016;37:259-262.

39. Keidar Z, Militianu D, Melamed E, Bar-Shalom R, Israel O. The diabetic foot: initial experience with 18F-FDG-PET/CT. J Nucl Med 2005;46:444-449.

40. Kagna O, Srour S, Melamed E, Militianu D, Keidar Z. FDG PET/ CT imaging in the diagnosis of osteomyelitis in the diabetic foot. Eur J Nucl Med Mol Imaging 2012;39:1545-1550.

41. Familiari D, Glaudemans AW, Vitale V, et al. Can sequential 18F-FDG PET/CT replace WBC imaging in the diabetic foot? J Nucl Med 2011;52:1012-1019.

42. Palestro CJ, Love C. Nuclear medicine and diabetic foot infections. Semin Nucl Med 2009;39:52-65.

43. Palestro $\mathrm{CJ}$, Mehta HH, Patel M, et al. Marrow versus infection in the Charcot joint: indium-111 leukocyte and technetium99m sulfur colloid scintigraphy. J Nucl Med 1998;39:346-350.

44. Höpfner S, Krolak C, Kessler S, et al. Preoperative imaging of Charcot neuroarthropathy in diabetic patients: comparison of ring PET, hybrid PET, and magnetic resonance imaging. Foot Ankle Int 2004;25:890-895.

45. Basu S, Chryssikos T, Houseni M, et al. Potential role of FDGPET in the setting of diabetic neuro-osteoarthropathy: can it differentiate uncomplicated Charcot's neuropathy from osteomyelitis and soft tissue infection? Nucl Med Commun 2007;28:465-472.

46. Palestro CJ. 18F-FDG and diabetic foot infections: the verdict is. J Nucl Med. 2011;52:1009-1011.

47. Treglia G, Sadeghib R, Annunziata S, et al. Diagnostic performance of Fluorine-18-Fluorodeoxyglucose positron emission tomography for the diagnosis of osteomyelitis related to diabetic foot: a systematic review and a metaanalysis. Foot (Edinb) 2013;23:140-148. 


\title{
DERLEME
}

DOI: $10.4274 /$ nts. 014

Nuclear Medicine Seminars / Nükleer Tıp Seminerleri 2016;2:95-103'de yayımlanan İngilizce makalenin 'bire bir' Türkçe versiyonudur.

\section{Diyabetik Ayak Enfeksiyonlarında Moleküler Görüntüleme}

\author{
Molecular Imaging of Diabetic \\ Foot Infections
}

Christopher J. Palestro

Hofstra Northwell Tıp Fakültesi, Radyoloji Anabilim Dalı, New York, ABD

Çevirmen: Evrim Sürer Budak

Antalya Kamu Hastaneleri Birliği Sağıık Bilimleri Üniversitesi, Antalya Eğitim ve Araştırma Hastanesi, Nükleer Tıp Kliniği, Antalya, Türkiye

\section{Öz}

Malleol altından itibaren kemik veya yumuşak dokuların enfeksiyonu olarak tanımlanan diyabetik ayak enfeksiyonu sık görülen bir klinik problemdir. Diyabetik hastalar ciddi bir enfeksiyon geçiriyor oldukları halde çok az belirti gösterebilirler veya hiç belirti vermeyebilirler ve osteomiyelit tanısı kolayca gözden kaçabilir. Bu nedenle, görüntüleme çalışmaları bu hastalarda tanısal işleyişin vazgeçilmez bir parçası haline gelmiştir. Çok spesifik veya sensitif olmamalarına rağmen direkt grafiler tanıda rutin olarak kullanılmaktadır. İlgili alanın anatomik değerlendirmesine ve takip eden prosedürün seçimini ve değerlendirmesini etkileyebilecek, önceden var olan durumların belirlenmesine olanak sağlarlar. Kemik sintigrafisi, sensitif olmasına rağmen spesifik değildir ve eğer kullanılacaksa tarama testi olarak kullanılmalıdır. Günümüzde, in-vitro işaretli lökosit sintigrafisi, diyabetik pedal osteomiyelitinin tanısında nükleer tıbbın altın standart yöntemidir. In-111 işaretli lökositlerin sensitivitesi \%72-100, spesifitesi \%67-100 arasında, Tc-99m işaretli lökositlerin ise sensitivitesi \%86-93, spesifitesi \%8098 aralığında değişmektedir. Inn-vivo olarak antigranülosit antikorları ve antikor fragmanları ile işaretlenen lökositlerle yapılmış çalışmaların sonuçları ise oldukça değişkendir. Ayrıca bu ajanlar her yerde bulunmamaktadır. İn-vitro ve invivo işaretli lökosit çalışmalarının, görüntü rezolüsyonunun kötü olması ve değerlendirilen yapıların küçük olması gibi kısıtlılıkları vardır. Tek foton emisyon bilgisayarlı tomografi/ bilgisayarlı tomografi (SPECT/BT) prosedüre dahil edilmesi ile işaretli lökosit tutulum odağı kesin bir şekilde lokalize edilmekte, yumuşak doku ve kemik enfeksiyon ayrımı kolaylaşmakta ve değerlendirmenin güvenilirliği ve testin

\begin{abstract}
Diabetic foot infection, which is defined as an infection of the soft tissues or bone below the malleoli, is a common clinical problem. Diabetic patients can have a significant foot infection with few or no signs or symptoms and the diagnosis of osteomyelitis can easily be overlooked. As a result, imaging studies have become an integral part of the diagnostic workup of these patients. Although not especially sensitive or specific radiographs are routinely performed because they provide an anatomic overview of the area of interest and any pre-existing conditions that could potentially influence the selection and interpretation of subsequent procedures. Bone scintigraphy is sensitive but not specific, and if used at all, should used as a screening procedure. In-vitro labeled leukocyte scintigraphy is, at the moment, the nuclear medicine gold standard for diagnosing diabetic pedal osteomyelitis, with sensitivity and specificity ranging from $72 \%$ to $100 \%$ and $67 \%$ to $100 \%$, respectively for $\ln -111$ labeled leukocytes and $86 \%$ to $93 \%$ and $80 \%$ to $98 \%$, respectively, for Tc-99m labeled leukocytes. Results obtained with leukocytes labeled in-vivo with antigranulocyte antibodies and antibody fragments, have been more variable. Furthermore, these agents are not widely available. In-vitro and in-vivo labeled leukocyte imaging studies are limited by a combination of poor image resolution and the small size of the structures being evaluated. Incorporating single photon emission computed tomography/computed tomography (SPECT/CT) into the procedure improves the accuracy of the test by precisely localizing foci of labeled leukocyte accumulation, facilitating the differentiation of soft tissue and bone infection, and improving confidence of interpretation. Furthermore, the
\end{abstract}


doğruluğu artmaktadır. Ayrıca yöntemin BT komponentinin prognostik değeri de vardır. Yakın zamandaki gelişmeler, pedal osteomiyeliti olan diyabetik hastalarda antibiyotik tedavisinin başarısını değerlendirmede SPECT/BT'nin yararlı olabileceğini göstermiştir. F-18 florodeoksiglukoz (FDG) pozitron emisyon tomografinin (PET) tek foton emisyonu yapan radyofarmasötiklere oranla pek çok avantajı bulunmaktadır. PET, yüksek rezolüsyonlu tomografik bir tekniktir. FDG, perfüzyonu kötü alanlara bile hızlıca girebilen küçük bir moleküldür. İşlem günler yerine saatler içinde tamamlanır ve zahmetli bir işaretleme prosedürü gerektirmez. Maalesef, FDG-PET ve PET/BT'nin diyabetik ayak enfeksiyonlarının tanısal işleyiş̧indeki rolü ile ilgili veriler yetersiz ve zaman zaman da çelişkilidir. Bu testin diyabetik ayak enfeksiyonlarındaki rolünü değerlendirmek için uniform bir referans standardı ve işaretli lökosit görüntüleme ile daha kapsamlı karşılaştırmalar içeren geniş, çok merkezli çalışmalar gerekmektedir. Anahtar kelimeler: Diyabet, florodeoksiglukoz, lökosit işaretli, osteomiyelit, PET/BT, SPECT/BT

\section{Giriş}

Malleol altından itibaren kemik veya yumuşak dokuların enfeksiyonu olarak tanımlanan diyabetik ayak enfeksiyonu sık görülen bir klinik problemdir. Bu enfeksiyonların çoğu travmatik veya ülsere olmuş deri alanından kaynaklanır. Tahmini olarak, diyabetik bir hastada hayatı boyunca ayak ülseri gelişme riski \%15-25 arasındadır, yıllık oran ise \%3-10 arasında değişmektedir. Diyabetik ayak enfeksiyonuna neden olan predispozan faktörlerin başında periferik arter hastalığı, periferik nöropati ve immün bozukluklar gelmektedir. Tüm nontravmatik alt ekstremite ampütasyonlarının $\% 50$ 'sinden fazlası diyabetik ayak enfeksiyonlarına bağlıdır ve diyabetli hastalardaki alt ekstremite ampütasyonuna giden süreçte $\% 85^{\prime}$ inde öncesinde ülser öyküsü bulunmaktadır $(1,2,3)$.

Diyabetik bir hastada ayak derisinin bütünlüğünün bozulduğu her durumda, pek çok ciddi yumuşak doku ve/veya kemik enfeksiyonu gelişme riski bulunmaktadır. Genel olarak hastalarda kronik, iyileşmeyen özellikle de dermisin ötesine geçen enfeksiyonlarda osteomiyelit akla gelmelidir. "Exposed bone" veya "probe to bone" testinin uygulanması kolay olup, açık bir yarada gelişen osteomiyeliti tanımada sensitivitesi ve spesifitesi sırasıyla \%60 ve \%91'dir (4). Diyabetli hastalarda ciddi
CT component of the examination may have prognostic value. Recent developments suggest that SPECT/CT also may be useful for determining the success of antibiotic treatment in diabetic patients with pedal osteomyelitis. F-18 fluorodeoxyglucose (FDG) positron emission tomography (PET) has several advantages over single photon emitting radiopharmaceuticals. PET is a high resolution tomographic technique. FDG is a small molecule that enters poorly perfused areas quickly. The procedure is completed in hours rather than days and no laborious labeling procedures are involved. Unfortunately, the available literature on the role of FDG-PET and PET/CT in the diagnostic workup of diabetic foot infections is inconclusive and at times contradictory. Large multicenter trials, including a uniform reference standard and more extensive comparison with labeled leukocyte imaging are needed to establish the role of this test in diabetic foot infections.

Keywords: Diabetes, fluorodeoxyglucose, labeled leukocytes, osteomyelitis, PET/CT, SPECT/CT bir ayak enfeksiyonu hiçbir semptom vermeyebilir ya da çok az bulgu verebilir, sistemik bir enflamatuvar yanıt da oluşturamadıklarından bu hastalarda osteomiyelit tanısı kolayca gözden kaçabilir (5). Bu nedenlerle, görüntüleme yöntemleri ayak enfeksiyonu olan diyabetik hastalarda tanısal işleyişin vazgeçilmez bir parçasıdır.

Direkt grafiler, sensitifiteleri yaklaşık \%54, spesifiteleri yaklaşık \%68 oranında olmasına rağmen kolay uygulanabilir ve nispeten ucuz olmalarından dolayı seçilecek ilk görüntüleme yöntemi olmalıdır. Tanı koydurucu olmasalar da ilgili alanın anatomik değerlendirmesine ve önceden var olan durumların tespitine olanak sağlayarak bir sonraki görüntüleme prosedürünün seçiminde ve değerlendirilmesinde yol gösterici olurlar (4). Her ne kadar manyetik rezonans görüntüleme de (MRG) ayak enfeksiyonu olan diyabetik hastaların tanısında çok önemli bir role sahip olsa da konu bu derlemenin kapsamının dışındadır, bu yazıda moleküler görüntüleme yöntemleri üzerinde durulacaktır.

\section{Moleküler Görüntüleme}

\section{Kemik Sintigrafisi}

Üç fazlı kemik sintigrafisinde osteomiyelit klasik olarak fokal hiperperfüzyon, fokal hiperemi ve fokal 
kemik tutulumu şeklinde gözlenir. Diyabetik bir hastada sıklıkla görülebilecek fraktür, nöropatik eklem ve hatta pedal ülseri gibi durumlar osteomiyeliti taklit edebilir (6) (Şekil 1, 2). Üç fazlı kemik sintigrafisinin sensitivitesi \%75100 , spesifitesi \%0-59 arasında değişmektedir $(7,8,9,10$, $11,12,13,14,15,16,17,18)$. Üç fazlı kemik sintigrafisinin spesifitesini arttırmak için akış fazında arteriyel ve venöz hiperperfüzyonu ayırmak veya çalışmaya geç görüntü/2. gün görüntülemenin eklenmesi (bu durumda dört fazlı kemik sintigrafisi adını almaktadır) gibi yöntemler denenmiştir, ancak bunların da sonuçları oldukça karmaşık olup rutin kullanıma geçmemiştir $(19,20,22,23)$.

\section{İşaretli Lökosit Görüntüleme}

İn-vitro işaretli lökosit sintigrafisi, diyabetik ayak osteomiyelitinin tanısında uzun zamandır altın standart moleküler yöntem olarak kullanılmaktadır. İndium-111 işaretli lökositler kullanılarak yapılan planar görüntülemenin diyabetik ayak osteomiyeliti tanısında sensitivitesi \%72-100, spesifitesi \%67-100 arasında değişmektedir (Şekil 3) $(7,8,9,10,14,20,21)$. Tc-99m eksametazime işaretli lökosit planar görüntülemenin ise sensitivitesi \%86-93, spesifitesi \%80-98 arasında değişmektedir $(11,12,13,17,24)$. Inn-vitro işaretli lökosit görüntülemenin yetişmiş donanımlı personel
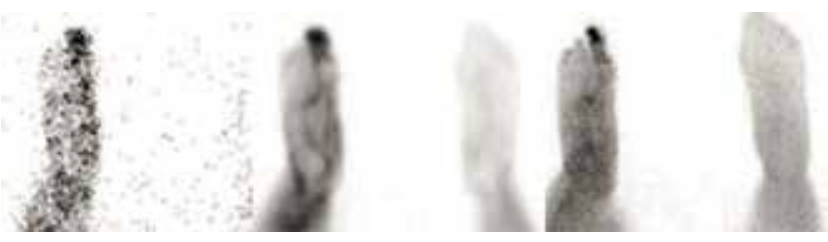

Şekil 1. Sağ ayak baş parmağında osteomiyelit: Üç fazlı kemik sintigrafisinde sağ ayak baş parmağında fokal hiperperfüzyon, fokal hiperemi ve kemikte fokal aktivite artışı dikkati çekmektedir. (Palestro CJ, Love C. Nuclear medicine and diabetic foot infections. Semin Nucl Med. 2009;39:52-65)
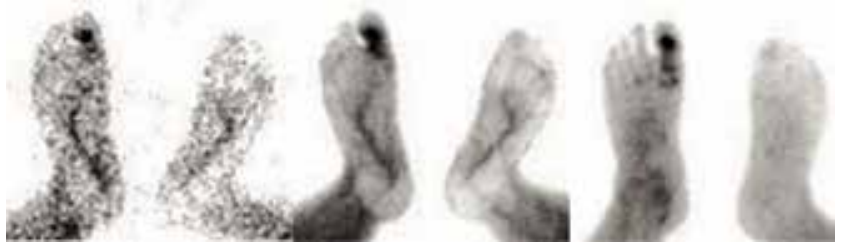

Şekil 2. Sol ayak baş parmağında reaktif değişiklikler. Sol ayak baş parmağında Şekil 1 ile karşılaştırıldığında- osteomiyelit ile benzer şekilde fokal hiperperfüzyon, fokal hiperemi ve kemikte fokal aktivite artışı dikkati çekmektedir. (Palestro CJ, Love C. Nuclear medicine and diabetic foot infections. Semin Nucl Med. 2009;39:52-65) gerektirmesi, zahmetli olması, her zaman uygulanabilir olmaması ve kan ile doğrudan temas gerektirmesi gibi bilinen pek çok limitasyonu vardır. Bu nedenlerle, in-vivo lökosit işaretleme metodları geliştirmek için çok sayıda çalışmalar yapılmıştır. Bu çalışmaların çoğu antigranülosit antikorları ve antikor fragmanları üzerine odaklanmıştır. Besilesomab, çapraz reaksiyon antijen-90'a bağlanan bir fare monoklonal immünoglobulin $\mathrm{G} 1$ (IgG1) antikorudur. $\mathrm{Bu}$ antijen, granülosit ve granülosit öncüllerinin hücre membranından eksprese edilir. Uygulamadan 45 dakika sonra Tc- $99 \mathrm{~m}$ besilesomabın \%10'u nötrofillere bağlanmaktadır. Diğer \%20'si dolaşımda serbest kalır ve non-spesifik mekanizmalar üzerinden enfeksiyon alanında tutulur (25). Dominguez-Gadea ve ark., Tc-99m besilesomabın diyabetik ayak osteomiyelitinin tanısında sensitivitesinin \%93, spesifitesinin $\% 78$, ve doğruluğunun \%84 olduğunu belirtmişlerdir (26). Schwegler ve ark.'ın çalışmasında ise sensitivite, spesifite ve doğruluk oranları sırasıyla \%29, \%85 ve \%65 olarak bulunmuştur (27). Tc-99m besilesomab verilen hastalarda "insan antifare antikor" (HAMA) yanıtının gelişme oranı $125 \mu \mathrm{g}$ tek doz antikor uygulaması sonrası \%5, tekrarlayan dozlarda ise \%30 olarak bildirilmiştir, bu da testin önemli bir dezavantajıdır. Sonuç olarak, hastalar öncesinde HAMA açısından değerlendirilmeli, $250 \mu \mathrm{g}$ 'dan fazla antikor enjekte edilmemeli ve tekrarlayan enjeksiyonlardan kaçınılmalıdır (25).

Antikor fragmanları ise bir HAMA yanıtı oluşturmazlar. Sulesomab, lökositlerde bulunan normal, çapraz reaksiyon-90'a bağlanan IgG1 sınıfı murin monoklonal antikorunun $50 \mathrm{kDa}$ luk antijen bağlayan (Fab') bölümüdür. Enjekte edilen Tc-99m sulesomabın yaklaşık \%3-6'sı dolaşımdaki nötrofillere bağlanırken, enjeksiyondan 24 saat sonra kalan aktivitenin \%35'i kemik iliğinde toplanmaktadır. ilk çalışmaların sonuçları

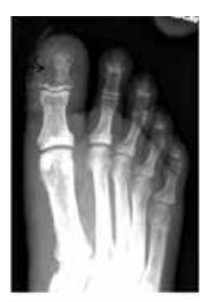

A

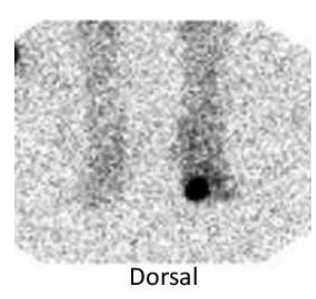

B

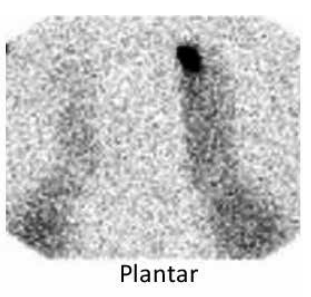

Şekil 3. Sol ayak baş parmağında osteomiyelit. (A): Direkt grafide yumuşak dokuda şişlik, medialde deride ülserasyon ve distal falankslarda düzensiz osteolizis ve (B) dorsal ve plantar In-111 işaretli lökosit görüntülerinde fokal artmış aktivite tutulumu gözlenmektedir 
enfeksiyondaki sulesomab tutulumunun, dolaşımdan enfeksiyon odağına göç eden nötrofillere ve zaten enfeksiyon odağında bulunan lökositlere bağlanma üzerinde olduğu yönündedir. Bir diğer görüş ise, sulesomabın dolaşımdaki lökositlere bağlanmadığı, enfeksiyon alanındaki tutulumun bu alandaki artmış kapiller permeabiliteye bağlı non-spesifik olarak gerçekleştiği yönündedir (25). Delcourt ve ark. 25 diyabetik hastadan oluşan prospektif çalışmalarında, kombine Tc-99m sulesomab/kemik görüntüleme ile kemik/galyum görüntülemeyi karşılaştırmışlardır (28). Tc-99m sulesomab/kemik görüntülemenin sensitifitesi $\% 67$, spesifitesi $\% 85$ ve doğruluk oranı $\% 74$ bulunurken kemik/galyum görüntüleme için bu oranlar sırasıyla $\% 44, \% 77$ ve $\% 58$ olarak bulunmuştur. Harwood ve ark. ayak ülseri bulunan 122 diyabetik hasta ile yaptıkları çalışmalarında Tc-99m sulesomabın pedal osteomiyelit tanısındaki sensitivitesini \%91, spesifitesini \%56 ve doğruluğunu \%80 olarak bulmuşlardır (29). Test in-vitro lökosit işaretleme yöntemine oranla anlamlı olarak daha sensitif (\%92 vs. $\% 79, p<0,05)$, hafifçe daha az spesifik (\%58 vs. \%67), kemik sintigrafisine oranla ise anlamlı olarak daha spesifik (\%50 vs. $\% 21, p<0,05$ ) bulunmuştur.

Hem in-vitro hem de in-vivo işaretli lökosit görüntülemenin doğruluk oranı, zayıf görüntü rezolüsyonu ve değerlendirilen yapıların boyutunun küçük olması nedeniyle oldukça sınırlıdır. Bazı araştırmacılar bu yöntemin doğruluk oranını arttırmak için tek foton emisyon bilgisayarlı tomografi/bilgisayarlı tomografiyi (SPECT/BT) kullanmışlardır. Heiba ve ark., indium işaretli lökosit çalışmalarında SPECT/BT kullanılarak yapılsa bile, yumuşak doku enfeksiyonu ile osteomiyelit ayrımı yapmanın her zaman mümkün olamadığını belirtmişledir (30). İki yüz on üç diyabetik hastada dual izotop işaretli lökosit/kemik SPECT/BT'yi eş zamanlı gerçekleştirmişler, gereklilik halinde ise kemik
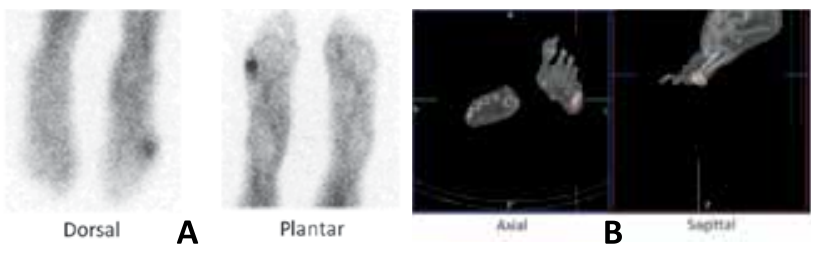

Şekil 4. Sol 5. metatars/falanksta osteomiyelit. Planar In-111 işaretli lökosit görüntülerinde sol ayak distal kesim lateralde artmış aktivite odağı izlenmektedir. Tek foton emisyon bilgisayarlı tomografi/bilgisayarlı tomografi görüntülerinde bu odağın kemik ve yumuşak dokuyu içerdiği dikkati çekmektedir iliği SPECT/BT yapmışlardır. Sonuç olarak, eş zamanlı dual izotop SPECT/BT'nin planar görüntülemeye ve tek izotop kemik ve In-111 lökosit SPECT/BT'ye oranla doğruluk oranının anlamlı olarak daha yüksek olduğunu bulmuşlardır. Dual izotop işaretli lökosit/kemik SPECT/ BT'yi eş zamanlı gerçekleştirmek, işaretli lökosit akümülasyonunun kesin şekilde lokalize edilmesini sağlamış böylece sonucun güvenilirliğini ve testin doğruluğunu iyileştirmiştir. Bir diğer çalışmada Heiba ve ark. diyabetik hastalarda ayak enfeksiyonlarının tanısında eş zamanlı dual izotop işaretli lökosit/kemik SPECT/ BT'yi konvansiyonel yöntemlerle karşılaştırmışlardır (31). Konvansiyonel görüntülemeye oranla dual izotop SPECT/BT, yumuşak doku enfeksiyonları, osteomiyelit ve diğer kemik anormalliklerinin tanısında daha yüksek "reader confidence" ve daha yüksek doğruluk göstermiştir. Bunun neticesi olarak dual izotop SPECT/ BT kullanımı ile gereksiz ampütasyonlar azalmış, organ koruyucu yaklaşımlar artmıştır. Bir diğer önemli nokta da ekonomik getirisidir, dual izotop SPECT/BT kullanımı ile konvansiyonel yöntemlere oranla hastanede kalış süreleri kısalmıştır.
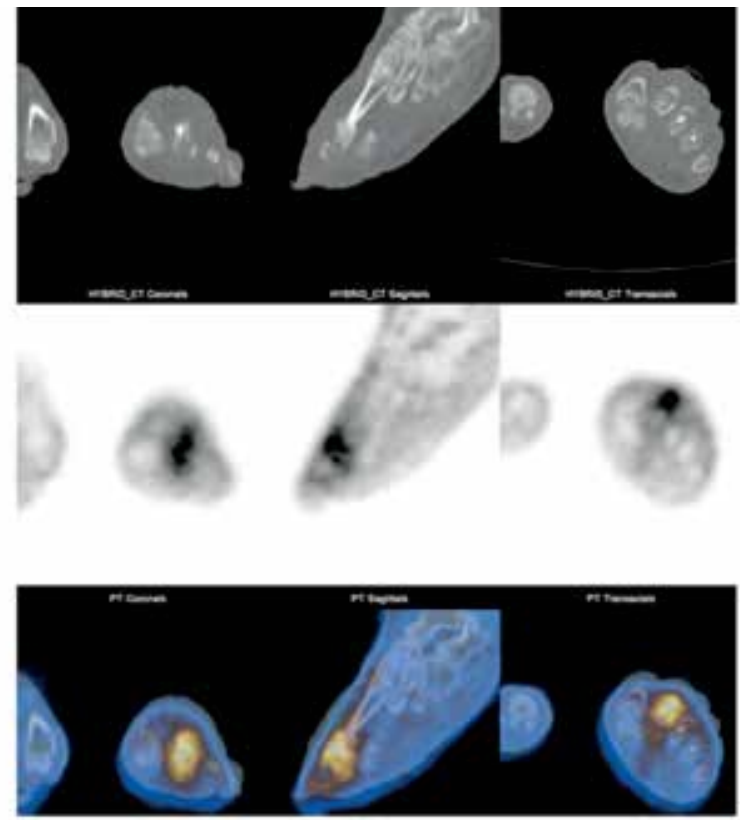

Şekil 5. Sol ayak ön kesimde osteomiyelit/septik artrit. Florodeoksiglikoz pozitron emisyon tomografi görüntüsünde sol ayak ön kesimde artmış aktivite tutulumu izlenmekle beraber bu alanda kemik tutulumu açısından yorum yapmak oldukça güçtür; pozitron emisyon tomografi/bilgisayarlı tomografi görüntüsünde aktivite tutulumunun sol 2 . distal metatars ve 2 . proksimal falanks ile metatarsofalengeal eklem aralığına karşılık geldiği dikkati çekmektdir. (O. Israel, M.D. izniyle) 
Dual izotop SPECT/BT'de bir diğer alternatif indium işaretli lökositler yerine teknesyum kullanılmasıdır. Teknesyumun rezolüsyonu daha yüksektir ve işaretleme ile görüntülemenin aynı gün yapılabilmesine olanak sağlar. Filippi ve ark. 19 şüpheli enfeksiyon alanı olan 17 diyabetik hastaya planar ve SPECT/BT teknesyum işaretli lökosit görüntüleme yapmışlardır. SPECT/BT görüntüleme işaretli hücrelerin enjeksiyonundan 6 saat sonra yapılmıştır (32). On dokuz alanın 16'sında işaretli lökosit görüntüleme pozitif olarak bulunmuştur. SPECT/BT, planar ve SPECT görüntüleme sonuçlarını 10 tutulum alanında (\%53) değiştirmiştir, buna göre altı alanda osteomiyelit tanısı dışlanmış, üç alanda yumuşak doku ve kemik enfeksiyonu tanımlanmış ve bir alanda osteomiyelit tanısı konmuştur. Araştırmacılar, teknesyum işaretli lökosit görüntüleme protokolüne SPECT/BT eklenmesinin diyabetik ayak enfeksiyonunda tanısal doğruluğu arttırdığı sonucuna varmışlardır. Przybylski ve ark. tamamında ayak ülseri olan 14 diyabetik hastaya ait teknesyum işaretli lökosit SPECT/BT görüntülerini retrospektif olarak değerlendirmişlerdir (33). Bu 14 hastanın beş tanesinde aynı zamanda periferik damar hastalığı da bulunmaktaydı. Görüntüleme işaretli lökosit enjeksiyonundan yaklaşık 3 saat sonra gerçekleştirildi. Testin sensitivitesi $\% 87,5$; spesifitesi $\% 71,4$ ve doğruluğu $\% 80$ olarak bulundu. Erdman ve ark. diyabetik ayak enfeksiyonu olan hastalarda prognozu öngörebilmek amacıyla hastalığın ciddiyetini sınıflandırmaya çalıştılar ve bu amaçla teknesyum işaretli lökosit SPECT/BT görüntülerinde Composite Severity Index (CSI) skorlama
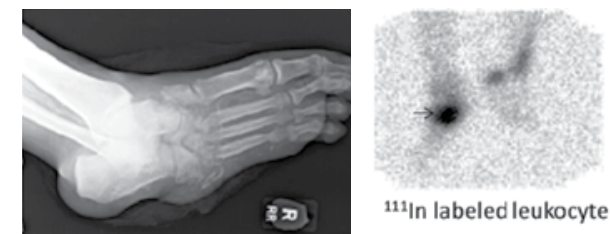

${ }^{111}$ In labeled leukocyte

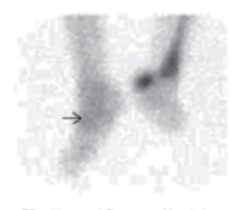

${ }^{99 m}$ TC sulfur colloid A

Şekil 6. Nöropatik eklem osteomiyeliti. (A): Direkt grafide ayak orta kesimde yoğun kemik erozyonunun eşlik ettiği düzensizlik, kemikte parçalanma ve debris formasyonu ile karakterli nöropatik eklem görünümü izlenmekte olup bu tabloya eşlik eden bir osteomiyeliti dışlamak oldukça zordur. (B): Indium-işaretli lökosit görüntüsünde (solda) sağ ayak orta kesimde yoğun artmış aktivite tutulumu (ok) izlenmektedir. Kemik iliği görüntülemesinde (sağda) bu alanda tutulum gözlenmemesi ile çalışma osteomiyelit açısından pozitif olarak değerlendirilmektedir. Ayrıca sol ayak arka kesimde de hem işaretli lökosit hem kemik iliği çalışmasında artmış aktivite tutulumu dikkati çekmekte olup bu fonksiyonel kemik iliği aktivitesini göstermektedir sistemini geliştirdiler (34). SPECT/BT görüntülerinde anahtar anatomik ve moleküler parametreler kullanılmasının tanısal ve prognostik bilgi sağlayabileceği hipotezini ortaya koydular. Bu amaçla işaretli lökosit tutulumunu retrospektif olarak değerlendirdiler ve derecelendirdiler, lezyon sayısı ve anatomik lokalizasyonu ile BT görüntüleri üzerinden tutulum komşuluğunda bozulmuş/düzensiz kemik yapılanması varlığını/yokluğunu not ettiler. CSI skoru bu veriler üzerinden elde edildi ve görüntülerin ikili değerlendirme sonuçları (osteomiyelit açısından pozitif veya negatif) ile karşılaştırıldı. Araştırmacılar olası olumlu prognostik sonuçların CSI skorları ile ters şekilde ilişki gösterdiğini gözlemlediler. CSI skoru arttıkça olumlu sonuç ihtimalinin azaldığını ve tedavi başarısızlık ihtimalinin arttığını buldular. Tedavi sonuçlarını öngörmede CSI, ikili değerlendirmeye oranla anlamlı olarak daha yüksek doğruluk oranına sahip bulundu $(p=0,016)$.

Yıllardır, araştırmacıların çok büyük kısmı işaretli lökosit görüntülemenin diyabetik ayak enfeksiyonundaki tanısal rolüne odaklanmış ancak tedavi yanıtı değerlendirmesi üzerinde çok durulmamıştır. Newman ve ark. 28 'inde osteomiyelit tanısı biyopsi ile kanıtlanmış 41 adet pedal ülseri olan 35 diyabetik hastada seri planar indium işaretli lökosit görüntüleme yapmışlardır (20). İşaretli lökosit aktivitesinin yoğunluğunun, uygun antibiyotik tedavi sonrası 16-34. günlerde azaldığını ve 36-54. günlerde normale döndüğünü bildirmişlerdir. Ancak bu verileri prognostik değerlendirme amacıyla kullanmamışlardır. Son dönemlerde, teknesyum işaretli lökosit SPECT/BT'nin diyabetik pedal osteomiyeliti olan hastaların tedavi yanıtını değerlendirmede kullanılabileceğine dair veriler vardır. Vouillarmet ve ark. 29 hastada, 1 yıllık takip sonrasında pedal osteomyelit remisyonunu değerlendirmek amacıyla direk grafi, üç fazlı kemik sintigrafisi ve teknesyum işaretli lökosit SPECT/BT' yi karşılaştırdılar (35). Direkt grafiler 16'sında relaps gelişen bazal 20 hastada hastalık kötüleşmesi ya da progresyonu göstermedi. Dokuz hastada radyolojik kötüleşme gösterilirken bunların bir tanesinde relaps gelişti. Üç fazlı kemik sintigrafisi pozitif olan 26 hastadan sadece beş tanesinde relaps gelişti. Üç fazlı kemik sintigrafisi negatif olan üç hastanın hiçbirinde ise relaps gözlenmedi. Teknesyum işaretli lökosit SPECT/BT görüntüleme işaretli lökositlerin enjeksiyonundan 20 saat sonra geçekleştirildi, 22 hastada negatif olarak izlendi ve bu hastaların hiçbirinde relaps gelişmedi. Yedi çalışma pozitif olarak değerlendirilirken bunlardan beş tanesinde 
relaps gelişti. Antibiyotik tedavisinin tamamlanmasından sonra osteomiyelit relapsını öngörmedeki sensitivite, spesifite, pozitif ve negatif öngörü değerleri direkt grafiler için sırasıyla $\% 80, \% 33, \% 20$ ve $\% 89$ olarak bulunurken üç fazlı kemik sintigrafisi için sırasıyla \%100, $\% 12,5, \% 15,5$ ve $\% 100$, teknesyum işaretli lökosit SPECT/ BT için \%100, \%91,5, \%71,5 ve \%100 olarak bulunmuştur. Araştırmacılar negatif bir çalışmanın güvenilir bir şekilde diyabetik ayak osteomiyelit remisyonunu gösterdiği ve antibiyotik tedavisine yol göstermesi açısından potansiyel olarak çok faydalı olduğu sonucuna varmışlardır.

Lazaga ve ark. diyabetik ayak osteomiyeliti olan 20 hastanın tedavi öncesi ve sonrası teknesyum işaretli lökosit SPECT/BT görüntülerini tedavi yanıtını değerlendirmek için retrospektif olarak yeniden gözden geçirdiler (36). Tedavi başarısı, yarada iyileşme veya son 1 yıl içerisinde aynı alanda enfeksiyonun tekrarlamaması olarak tanımlandı. Tedavi başarısını belirlemede sensitivite, spesifite, pozitif ve negatif öngörü değeri sırasıyla \%90, \%56, \%69 ve \%83 olarak bulundu.

$\mathrm{Bu}$ ilk sonuçlar, teknesyum işaretli lökosit SPECT/ BT'nin diyabetik pedal osteomiyeliti olan hastalarda tedavi yanıtını değerlendirmede yararlı bir tetkik olabileceği yönündedir. Test, negatif olduğu durumlarda enfeksiyon relaps ihtimalini belirgin oranda dışlaması açısından özellikle değerlidir.

\section{F-18 Florodeoksiglikoz}

F-18 florodeoksiglikoz (FDG) pozitron emisyon tomografinin (PET) tek foton emisyonu yapan radyofarmasötiklere oranla pek çok avantajı bulunmaktadır. PET, esasen radyofarmasötik akümülasyonunun kesin şekilde lokalizasyonuna olanak sağlayan yüksek rezolüsyonlu tomografik bir tekniktir. FDG, perfüzyonu kötü alanlara bile hızlıca girebilen küçük bir moleküldür. İşlem günler yerine saatler içinde tamamlanır ve in-vitro lökosit işaretlemenin tersine zahmetli bir işaretleme prosedürü gerektirmez. Travmatik kemikteki FDG tutulumu genellikle 3-4 ayda normale döner ve dejeneratif değişikliklerde hafifçe artmış bir tutulum gözlenir (6).

Pek çok araştırmacl, FDG-PET ve PET/BT'nin diyabetik ayak enfeksiyonlarını değerlendirmedeki rolünü araştırmışlardır. Nawaz ve ark. 110 diyabetik hastada pedal osteomiyelit tanısında FDG-PET, direkt grafi ve MRG'nin rolünü hastaların tümüne bu üç prosedürün hepsi uygulanmamış olsa da- prospektif olarak karşılaştırmışlardır (37). Hastaların tamamında kan şeker düzeyi $200 \mathrm{mg} / \mathrm{dL}^{\prime}$ nin altındaydı. Hastalar görsel olarak değerlendirilmiş olup SUV değerlendirmesi yapılmamıştır. FDG-PET için sensitivite, spesifite, pozitif ve negatif öngörü değeri ile doğruluk değerleri sırasıyla $\% 81, \% 93, \% 78, \% 94$ ve $\% 90$ olarak bulunmuştur. MRG için bu değerler sırasıyla \%91, \%78, \%56, \%97 ve $\% 81$; direkt grafi içinse $\% 63, \% 87, \% 60, \% 88$ ve $\% 81$ olarak bulunmuştur. Sonuç olarak FDG-PET'in diyabetik ayak osteomiyelitinin tanısında oldukça spesifik ve MRG'yi tamamlayıcı faydalı bir tetkik olduğu sonucuna varılmıştır. Araştırmacılar ayrıca MRG'nin yapılamadığı zamanlarda FDG-PET'in direkt grafilerin negatif veya sonuçsuz olduğu durumlardan sonra kullanılabileceğini belirtmişlerdir.

Pedal osteomiyeliti olan diyabetik hastaların çok büyük kısmı distal ön ayakta ülserler ile presente olur, ülser olmaksızın pedal osteomiyeliti çok nadirdir. Maalesef ilgili alanlarla (ön ayak, orta ayak, arka ayak) ait bilgiler ve yumuşak doku ülseri olan hasta sayısı bilinemediğinden bu bulguların önemi değerlendirilememiştir.

Schwegler ve ark.'nın çalışmasının sonuçları oldukça farklıdır (27). Bu araştırmacılar klinik olarak şüphe götürmeyen, iyileşmeyen pedal ülseri olan 20 diyabetik hastada prospektif olarak FDG-PET'in tanısal rolünü sadece görsel olarak değerlendirmişlerdir. Pedal ülserler 18 hastada ön ayakta, iki hastada ise arka ayakta lokalizedirler. Görüntüleme sırasındaki kan glukoz değerleri ile ilgili bilgi bulunmamaktadır. FDG-PET için sensitivite, spesifite ve doğruluk değeri sırasıyla \%29, \%92 ve $\% 70$ olarak bulunurken MRG için bu değerler sırasıyla $\% 86, \% 92$ ve $\% 90$ olarak bulunmuştur. Araştırmacılar testin düşük sensitivitesinin çalışma popülasyonundaki azalmış enflamatuvar yanıta ve/veya insülin direncine sekonder FDG'nin bozulmuş kemik tutulumuna bağlı olabileceğini belirtmişlerdir. Hareket artefaktları ve uzaysal rezolüsyonun sınırlı olması da bu duruma katkıda bulunmuş olabilir. Araştırmacılar iyileşmeyen pedal ülseri olan diyabetik hastalarda osteomiyelit tanısında MRG'nin tercih edilecek görüntüleme yöntemi olabileceği sonucuna varmışlardır.

Yang ve ark. şüpheli pedal osteomiyeliti olan 48 diyabet hastası ile çalışmışlardır, bunların 27 tanesinde kan glukoz düzeyi $150 \mathrm{mg} / \mathrm{dL}$ 'nin üstündedir (28). FDGPET'in doğruluk oranı \%93,8 olarak bulunmuştur. Serum glukoz değeri $150 \mathrm{mg} / \mathrm{dL}$ 'nin üzerinde olan hastalarda sensitivite \%88,9; $150 \mathrm{mg} / \mathrm{dL}^{\prime}$ nin altında olan hastalarda $\% 88,3$ olarak bulunmuştur. Çalışmada hafif-orta düzeyli 
artmış serum glukoz düzeylerinin diyabetik hastalarda pedal osteomiyelit tanısında FDG-PET'in doğruluğunu etkilemediği sonucuna varılmıştır.

Keidar ve ark. 14 diyabetik hastaya ait 18 klinik olarak şüpheli enfeksiyon alanında FDG-PET ile PET/BT'yi karşılaştırmışlardır (39). On sekiz şüpheli enfeksiyon alanından yedi tanesi ayak ön kesimde, bir tanesi orta kesimde ve kalan 10 tanesi arka kesimde yer almaktaydı. Kan glukoz düzeyleri $84-330$ mg/ $\mathrm{dL}$ arasında değişmekte olup yedi hastada $200 \mathrm{mg} /$ dL'nin üzerindeydi. PET görüntülerinde enfeksiyon ile uyumlu 14 anormal tutulum alanı saptanırken PET/ BT ile bu 14 alandan 13 tanesi konfirme edildi. On üç tutulum alanından sekiz tanesi kemik, beş tanesi kemik ve yumuşak dokuda olacak şekilde doğru bir şekilde lokalize edildi. PET görüntülerinde bir tutulum alanı enfeksiyon olarak değerlendirilmiş olsa da bu alan PET/BT'de diyabetik osteoartropati olarak olarak tanımlandı. Anormal FDG tutulum alanlarındaki maksimum SUV değerleri 1,4-11,1 arasında ölçüldü. Hastaların kan glukoz düzeyleri ile FDG tutulum dereceleri arasında ilişki saptanmadı. Araştırmacılar FDG'nin diyabete bağlı ayak enfeksiyonlarının tanısında kullanılabileceği ve PET/BT şeklinde yapılması durumunda ise osteomiyelitin yumuşak doku enfeksiyonundan doğru bir şekilde ayırt edilebileceği sonucuna varmışlardır (Şekil 5). Kagna ve ark. bu araştırmayı genişleterek diyabetik pedal osteomiyelitinde sensitivite, spesifite ve doğruluk değerlerini sırasıyla \%100, \%93 ve \%96 olarak rapor etmişlerdir (40).

Familiari ve ark. yüksek pretest enfeksiyon olasılığı olan 13 diyabetik hastada FDG-PET/BT ile planar TcWBC görüntüleme yöntemini karşılaştırmışlardır (41). Tüm hastaların kan glukoz düzeyi 160 mg/dL'nin altında ölçülmüştür. Tüm olgularda kesin tanı histopatolojik olarak konfirme edilmiştir. Osteomiyelit tanısında teknesyum işaretli lökosit planar görüntülemenin sensitifite, spesifite, pozitif ve negatif öngörü değeri ile doğruluk değerleri sırasıyla \%86, \%100, \%100, \%86 ve \%92 olarak bulunmuştur. FDG-PET/BT için bu değerler sırasıyla $\% 43, \% 67, \% 60, \% 50$ ve $\% 54$ olarak bulunmuştur. Görüntüler değerlendirilirken BT bulgularının da göz önünde bulundurulması ile FDG-PET/BT'nin doğruluk oranı \%62'ye yükselmiştir. Araştırmacılar, FDG-PET/BT'nin tanısal doğruluğunun düşük olduğu ve diyabetik pedal osteomiyelitinin tanısında işaretli lökosit görüntülemenin yerini alamayacağı sonucuna varmışlardır.

Diyabetik ayak enfeksiyonu olan hastaların çoğunluğu distal ön ayak ülseri ile presente olur. Nöropatik/Charcot eklemi ise daha az görülmekle birlikte çoğunlukla ülser ile ilişkili değildir ve ayağın orta veya arka kısmında görülür. En sık tarsal ve tarsometatarsal (Lisfranc) eklem (\%60) tutulurken, bunu metatarsofalengeal (\%30) ve tibiotalar eklem (\%10) takip eder. Enfeksiyon/nöropatik eklem ayrımı veya nöropatik bir eklemde superempose olan enfeksiyon durumunda tanı zorlayıcıdır. Üç fazlı kemik sintigrafisi her iki durumda da pozitiftir. İşaretli lökositler hem enfekte hem de enfekte olmayan nöropatik eklemde akümüle olurlar. Enfekte olmayan nöropatik eklemdeki akümülasyon, çoğu durumda etkilenen kemikteki hematopoetik olarak aktif kemik iliğine bağlıdır. Tamamlayıcı olarak kemik iliği görüntülemesi yapılması ile işaretli lökosit akümülasyonunun kemik iliği aktivitesine mi yoksa enfeksiyona mı sekonder olduğunun ayrımı doğru bir şekilde yapılır (Şekil 6) (42). Palestro ve ark. planar In-WBC/kemik iliği görüntülemesi için \%95 bir doğruluk oranı belirtmişler, Heibe ve ark.'da dual izotop SPECT/BT kullanarak benzer sonuçlara ulaşmışlardır $(30,43)$.

Nöropatik eklem değerlendirmesinde FDG-PET ve PET/BT'nin rolü ile ilgili bilgiler sınırlıdır. Höpfner ve ark. nöropatik eklemin preoperatif değerlendirmesinde FDG PET'in rolünü 16 hastalık çalışmalarında değerlendirmişlerdir (44). Bu araştırmadaki hiçbir hastada osteomiyelit yoktu. Araştırmacılar her ne kadar çalışmaya alınan hastaların hiçbirisinde diyabetik ayak enfeksiyonu olmasa da enfekte olmayan nöropatik eklemde izlenen rölatif düşük tutulum nedeniyle FDG PET'in osteomiyeliti nöropatik eklem lezyonlarından ayırmada faydalı olabileceği sonucuna varmışlardır. Shagos ve ark. osteomiyelit $(n=36)$ ve nöropatik eklem $(n=43)$ gibi diyabetik ayak komplikasyonlarınının değerlendirmesinde FDG PET ile üç fazlı kemik sintigrafisini karşılaştırdılar (15). Buna göre osteomiyelit tanısında FDG PET'in üç fazlı kemik sintigrafisine oranla daha spesifik, nöropatik eklem tanısında ise üç fazlı kemik sintigrafisinin FDG PET'e orana daha sensitif olduğu sonucuna vardılar. Basu ve ark. FDG PET'in pedal osteomiyelit ve yumuşak doku enfeksiyonunu enfekte olmayan nöropatik eklemden ayırmadaki etkinliğini 
araştırdılar (45). FDG PET'in osteomiyelit tanısında sensitifitesi \%100, doğruluğu \%94 olarak bulundu. Araştırmacılar FDG PET'in nöropatik eklem varlığında osteomiyeliti ekarte edici yüksek negatif öngörü değeri olduğunu belirttiler. Maalesef bu çalışmada, sadece bir hastada nöropatik eklem üzerine süperempoze olmuş osteomiyelit tablosu söz konusuydu.

Mevcut kanitlara dayanarak FDG PET veya PET/ BT'nin diyabetik ayak osteomiyeliti tanısında seçilecek moleküler görüntüleme yöntemi olduğunu söylemek mümkün değildir. Mevcut verilerin, metodoloji ve hasta popülasyonlarındaki farklılıklar, görüntü değerlendirmesindeki farklılıklar (görsel vs. SUV), vasküler yetmezlik olup olmadığı ile ilgili bilgi eksikliği, MRG ile olan tutarsız korelasyonlar, işaretli lökosit görüntüleme ile karşılaştırmalı yapılan çalışmaların az olması ve uniform bir doğruluk standardının olmaması gibi limitasyonları bulunmaktadır $(46,47)$. Treglia ve ark. meta-analiz çalışmalarında FDG'nin diyabetik ayak osteomiyelitini tanımada sensitifitesini \%74, spesifitesini \%91 olarak belirttiler (47). Ayrıca şüpheli diyabetik ayak osteomiyelitinde FDG görüntüleme ile ilgili literatürün sınırlı olduğu ve referans standart olarak kemik biyopsisi kullanılarak yapılmış çok merkezli çalışmalara intiyaç olduğu yorumunda bulundular.

\section{Sonuç}

Ayak enfeksiyonu olan bir diyabetik hastada pedal osteomiyelit tanısı sıklıkla gözden kaçmaktadır ve bu hastalarda görüntüleme çalışmaları tanısal işleyişin vazgeçilmez bir parçası haline gelmiştir. Şu anda, in-vitro işaretli lökosit görüntüleme bu hasta popülasyonunda seçilecek moleküler görüntüleme yöntemidir. Yayınlanan veriler In-111 ve Tc-99m işaretli lökositlerin her ikisinin de kullanılabileceği ve sonuçlarının benzer olduğu yönündedir. Kullanılan radyo-işaretleyiciden bağımsız olarak, SPECT/BT rutin olarak kullanılmalıdır. SPECT/ BT'nin prosedüre dahil edilmesi ile "reader confidence" ve testin doğruluğu artmaktadır. SPECT/BT'nin aynı zamanda prognostik değeri de bulunabilmektedir ve tedavi yanıtını değerlendirmeye yardımcı olabilir. Diyabetik ayak enfeksiyonlarının tanısal değerlendirmesinde FDGPET ve PET/BT'nin kullanılması heyecan uyandırsa da bununla ilgili herhangi bir sonuca varmadan önce daha kapsamlı araştırmalar gerekmektedir.

\section{Kaynaklar}

1. Gemechu FW, Seemant F, Curley CA. Diabetic foot infections. Am Fam Physician. 2013;88:177-184.

2. Lipsky BA, Berendt AR, Cornia PB, et al. 2012 Infectious Diseases Society of America clinical practice guideline for the diagnosis and treatment of diabetic foot infections. Clin Infect Dis 2012;54:132-173.

3. Boulton AJ, Vileikyte L, Ragnarson-Tennvall G, Apelqvist J. The global burden of diabetic foot disease. Lancet 2005;366:17191724.

4. Dinh MT, Abad CL, Safdar N. Diagnostic accuracy of the physical examination and imaging tests for osteomyelitis underlying diabetic foot ulcers: meta-analysis. Clin Infect Dis 2008;47:519-527.

5. Anderson CA, Roukis TS. The diabetic foot. Surg Clin N Am 2007;87:1149-1177.

6. Palestro CJ. Radionuclide imaging of osteomyelitis. Sem Nucl Med 2015;45:32-46.

7. Keenan AM, Tindel NL, Alavi A. Diagnosis of pedal osteomyelitis in diabetic patients using current scintigraphic techniques. Arch Intern Med 1989;149:2262-2266.

8. Larcos G, Brown ML, Sutton R. Diagnosis of osteomyelitis of the foot in diabetic patients: value of 111 In-leukocyte scintigraphy. AJR Am J Roentgenol 1991;157:527-531.

9. Maurer $\mathrm{AH}, \mathrm{Millmond} \mathrm{SH}$, Knight LC, et al. Infection in diabetic osteoarthropathy: Use of indium-labeled leukocytes for diagnosis. Radiology 1986;151: 221-225.

10. Johnson JE, Kennedy EJ, Shereff MJ, Patel NC, Collier BD. Prospective study of bone, indium-111-labeled white blood cell, and gallium-67 scanning for the evaluation of osteomyelitis in the diabetic foot. Foot Ankle Int 1996;17;10-16.

11. Devillers A, Moissan A, Hennion F, Garin E, Poirier JY, Bourguet P. Contribution of technetium-99m hexamethylpropylene amine oxime labeled leucocyte scintigraphy to the diagnosis of diabetic foot infection. Eur J Nucl Med 1998;25:132-138.

12. Harvey J, Cohen MM. Technetium-99-labeled leukocytes in diagnosing diabetic osteomyelitis in the foot. J Foot Ankle Surg 1997;36:209-214.

13. Blume PA, Dey HM, Dailey LJ, Arrighi JA, Soufer R, Gorecki GA. Diagnosis of pedal osteomyelitis with Tc-99m HMPAO labeled leukocytes. J Foot Ankle Surg 1997;36:120-126.

14. Palestro CJ, Caprioli R, Love $C$, et al. Rapid diagnosis of pedal osteomyelitis in diabetics with a technetium-99m labeled monoclonal antigranulocyte antibody. J Foot Ankle Surg 2003;42:2-8.

15. Shagos GS, Shanmugasundaram P, Varma AK, Padma S, Sarma M. 18-F flourodeoxy glucose positron emission tomographycomputed tomography imaging: A viable alternative to three phase bone scan in evaluating diabetic foot complications? Indian J Nucl Med 2015;30:97-103. 
16. Sarikaya A, Aygit AC, Pekindil G. Utility of $99 \mathrm{mTc}$ dextran scintigraphy in diabetic patients with suspected osteomyelitis of the foot. Ann Nucl Med 2003;17:669-676.

17. Scheidler J, Leinsinger G, Pfahler M, Kirsch CM. Diagnosis of osteomyelitis. Accuracy and limitations of antigranulocyte antibody imaging compared to three-phase bone scan. Clin Nucl Med 1994;19:731-737.

18. Yuh WT, Corson JD, Baraniewski HM, et al. Osteomyelitis of the foot in diabetic patients: evaluation with plain film, 99mTc-MDP bone scintigraphy, and MR imaging. AJR Am J Roentgenol 1989;152:795-800.

19. Seldin DW, Heiken J, Feldman F, Alderson PO. Effect of soft tissue pathology on detection of pedal osteomyelitis in diabetics. J Nucl Med1985;26:988-993.

20. Newman LG, Waller J, Palestro CJ, et al. Unsuspected osteomyelitis in diabetic foot ulcers. Diagnosis and monitoring by leukocyte scanning with indium In 111 oxyquinoline. J Am Med Assoc 1991;266:1246-1251.

21. Johnson JE, Kennedy EJ, Shereff MJ, Patel NC, Collier BD. Prospective study of bone, indium-111-labeled white blood cell, and gallium-67 scanning for the evaluation of osteomyelitis in the diabetic foot. Foot Ankle Int 1996;17:10-16.

22. Alazraki N, Dries D, Datz F, Lawrence P, Greenberg E, Taylor A Jr. Value of a 24-hour image (four-phase bone scan) in assessing osteomyelitis in patients with peripheral vascular disease. J Nucl Med 1985;26:711-717.

23. Israel O, Gips S, Jerushalmi J, Frenkel A, Front D. Osteomyelitis and soft-tissue infection: differential diagnosis with 24 hour/4 hour ratio of Tc-99m MDP uptake. Radiology 1987;163:725-726.

24. Poirier JY, Garin E, Derrien C, et al. Diagnosis of osteomyelitis in the diabetic foot with 99mTc-HMPAO leukocyte scintigraphy combined with a 99mTc-MDP bone scintigraphy. Diabetes Metab 2002;28:485-490.

25. Palestro CJ, Glaudemans AWJM, Dierckx RAJO. Multiagent imaging of inflammation and infection with radionuclides. Clin Transl Imaging 2013;1:385-396.

26. Dominguez-Gadea L, Martin-Curto LM, de la Calle $H$, Crespo A. Diabetic foot infections: scintigraphic evaluation with 99Tcm-labelled anti-granulocyte antibodies. Nucl Med Commun 1993;14:212-218.

27. Schwegler B, Stumpe KD, Weishaupt D, et al.Unsuspected osteomyelitis is frequent in persistent diabetic foot ulcer and better diagnosed by MRI than by $18 \mathrm{~F}-\mathrm{FDG}$ PET or $99 \mathrm{mTc}-$ MOAB. J Intern Med 2008;263:99-106.

28. Delcourt A, Huglo $D$, Prangere $T$, et al. Comparison between Leukoscan (Sulesomab) and gallium-67 for the diagnosis of osteomyelitis in the diabetic foot. Diabetes Metab 2005;31:125-133.

29. Harwood SJ, Valdivia S, Hung GL, Quenzer, RW. Use of sulesomab, a radiolabeled antibody fragment, to detect osteomyelitis in diabetic patients with foot ulcers by leukoscintigraphy. Clin Infect Dis 1999;28:1200-1205.

30. Heiba SI, Kolker D, Mocherla B, et al. The optimized evaluation of diabetic foot infection by dual isotope SPECT/CT imaging protocol. J Foot Ankle Surg 2010;49:529-536.

31. Heiba S, Kolker D, Ong L, et al. Dual-isotope SPECT/CT impact on hospitalized patients with suspected diabetic foot infection: saving limbs, lives, and resources. Nucl Med Commun 2013;34:877-884.

32. Filippi L, Uccioli L, Giurato L, Schillaci O. Diabetic foot infection: usefulness of SPECT/CT for 99mTc-HMPAO-labeled leukocyte imaging. J Nucl Med 2009;50:1042-1046.

33. Przybylski MM, Holloway S, Vyce SD, Obando A. Diagnosing osteomyelitis in the diabetic foot: a pilot study to examine the sensitivity and specificity of $\mathrm{Tc}(99 \mathrm{~m})$ white blood cell-labelled single photon emission computed tomography/computed tomography. Int Wound J 2016;13:382-389.

34. Erdman WA, Buethe J, Bhore R, et al. Indexing severity of diabetic foot infection with $99 \mathrm{mTC}-\mathrm{WBC}$ SPECT/CT hybrid imaging. Diabetes Care 2012;35:1826-1831.

35. Vouillarmet J, Morelec I, Thivolet C. Assessing diabetic foot osteomyelitis remission with white blood cell SPECT/CT imaging. Diabet Med 2014;31:1093-1099.

36. Lazaga F, Van Asten SA, Nichols A, et al. Hybrid imaging with 99mTc-WBC SPECT/CT to monitor the effect of therapy in diabetic foot osteomyelitis. Int Wound J 2015.

37. Nawaz A, Torigian DA, Siegelman ES, Basu S, Chryssikos T, Alavi A. Diagnostic performance of FDG-PET, MRI, and plain film radiography (PFR) for the diagnosis of osteomyelitis in the diabetic foot. Mol Imaging Biol 2010;12:335-342.

38. Yang $H$, Zhuang $H$, Rubello $D$, Alavi A. Mild-to-moderate hyperglycemia will not decrease the sensitivity of 18F-FDG PET imaging in the detection of pedal osteomyelitis in diabetic patients. Nucl Med Commun 2016;37:259-262.

39. Keidar Z, Militianu D, Melamed E, Bar-Shalom R, Israel O. The diabetic foot: initial experience with 18F-FDG-PET/CT. J Nucl Med 2005;46:444-449.

40. Kagna O, Srour S, Melamed E, Militianu D, Keidar Z. FDG $\mathrm{PET} / \mathrm{CT}$ imaging in the diagnosis of osteomyelitis in the diabetic foot. Eur J Nucl Med Mol Imaging 2012;39:15451550.

41. Familiari D, Glaudemans AW, Vitale V, et al. Can sequential 18F-FDG PET/CT replace WBC imaging in the diabetic foot? J Nucl Med 2011;52:1012-1019.

42. Palestro CJ, Love C. Nuclear medicine and diabetic foot infections. Semin Nucl Med 2009;39:52-65.

43. Palestro $\mathrm{CJ}$, Mehta $\mathrm{HH}$, Patel $\mathrm{M}$, et al. Marrow versus infection in the Charcot joint: indium-111 leukocyte and technetium- 
99m sulfur colloid scintigraphy. J Nucl Med 1998;39:346350.

44. Höpfner S, Krolak C, Kessler S, et al. Preoperative imaging of Charcot neuroarthropathy in diabetic patients: comparison of ring $\mathrm{PET}$, hybrid $\mathrm{PET}$, and magnetic resonance imaging. Foot Ankle Int 2004;25:890-895.

45. Basu S, Chryssikos T, Houseni M, et al. Potential role of FDGPET in the setting of diabetic neuro-osteoarthropathy: can it differentiate uncomplicated Charcot's neuropathy from osteomyelitis and soft tissue infection? Nucl Med Commun 2007;28:465-472.

46. Palestro CJ. 18F-FDG and diabetic foot infections: the verdict is. J Nucl Med. 2011;52:1009-1011.

47. Treglia G, Sadeghib R, Annunziata S, et al. Diagnostic performance of Fluorine-18-Fluorodeoxyglucose positron emission tomography for the diagnosis of osteomyelitis related to diabetic foot: a systematic review and a metaanalysis. Foot (Edinb) 2013;23:140-148. 